\title{
Parametric Study and Preliminary Evaluation of Reverse Osmosis for Seawater Desalination
}

\author{
P. Glueckstern \\ S. A. Reed \\ J. V. Wilson
}

\section{OAK RIDGE NATIONAL LABORATORY}




\section{DISCLAIMER}

This report was prepared as an account of work sponsored by an agency of the United States Government. Neither the United States Government nor any agency Thereof, nor any of their employees, makes any warranty, express or implied, or assumes any legal liability or responsibility for the accuracy, completeness, or usefulness of any information, apparatus, product, or process disclosed, or represents that its use would not infringe privately owned rights. Reference herein to any specific commercial product, process, or service by trade name, trademark, manufacturer, or otherwise does not necessarily constitute or imply its endorsement, recommendation, or favoring by the United States Government or any agency thereof. The views and opinions of authors expressed herein do not necessarily state or reflect those of the United States Government or any agency thereof. 


\section{DISCLAIMER}

Portions of this document may be illegible in electronic image products. Images are produced from the best available original document. 
Printed in the United States of America. Available from

National Technical Information Service

U.S. Department of Commerce

5285 Port Royal Road, Springfield, Virginia 22161

Price: Printed Copy $\$ 4.50$; Microfiche $\$ 2.25$

This report was prepared as an account of work sponsored by the United States Government. Neither the United States nor the Energy Research and Development Administration/United States Nuclear Regulatory Commission, nor any of their employees, nor any of their contractors, subcontractors, or their employees, makes any warranty, express or implied, or assumes any legal liability or responsibility for the accuracy, completeness or usefulness of any information, apparatus, product or process disclosed, or represents that its use would not infringe privately nwened rights. 
ORNL/TM-5231

Contract No. W-7405-eng-26

Engineering Technology Division

PARAMETRIC STUDY AND PRELIMINARY EVALUATION OF REVERSE OSMOSIS FOR SEAWATER DESALINATION

P. Glueckstern S. A. Reed

J. V. Wilson

Date Published: November 1976

NOTICE: This document contains information of a preliminary nature. It is subject to revision or correction and therefore does not represent a final report.

Prepared by the

OAK RIDGE NA'I'IONAL LABORATORY

Oak Ridge, Tennessee 37830

operated by

UNION CARBIDE CORPORATION

for the

ENERGY RESEARCH AND DEVELOPMENT ADMINISTRATION

This repoit - NOTICE

This repott was prepared as an account of work the Unit by United States Government. Neither Research and Development Anited States Energy their employees, not administration, nor any of subcontractors, or their employers contraciors, warranty, express or implied, or assumes any iny tabifly or responsibility for the accuracy, completeness pr usefuness of any information, apparatus, product or process disclosed, or represents that its use' would not
infringe privately owned rights.
AND 


\section{THIS PAGE}

\section{WAS INTENTIONALLY \\ LEFT BLANK}


ACKNOWLEDGMENT $\ldots \ldots \ldots \ldots \ldots \ldots \ldots \ldots \ldots \ldots \ldots \ldots \ldots \ldots \ldots \ldots \ldots \ldots \ldots \ldots$

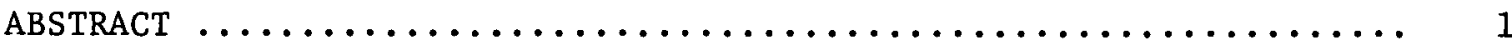

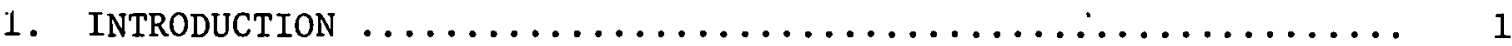

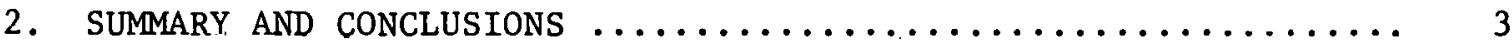

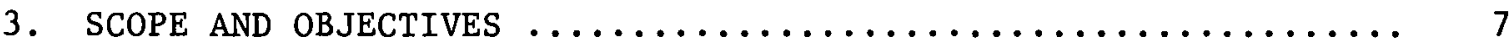

4. EVALUATION METHOD $\ldots \ldots \ldots \ldots \ldots \ldots \ldots \ldots \ldots \ldots \ldots \ldots \ldots \ldots \ldots \ldots \ldots \ldots \ldots \ldots$

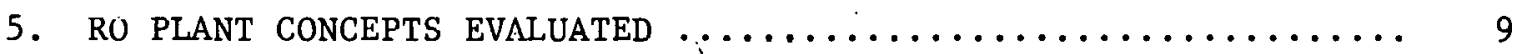

5.1 Process Description and Basic Assumptions ............ 9

5.2 Basic Design Criteria .......................... 11

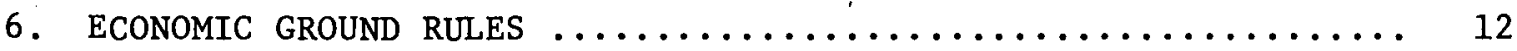

6.1 Bases for Estimating the Direct Capital Cost ......... 12

6.2 Bases for Estimating Indirect Capital and Total

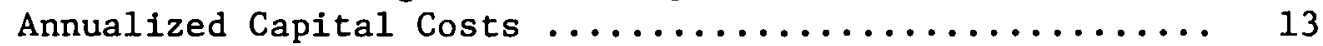

6.3 Bases for Estimating the Operating Costs ............ 13

7. RESULTS FOR OPTIMIZED RO SYSTEMS $\ldots \ldots \ldots \ldots \ldots \ldots \ldots \ldots \ldots \ldots \ldots .16$

7.1 Optimum Product Recovery and Other Design Data ......... 16

7.2 Capital Cost of the Optimized Ro Designs ............. 16

7.3 Unit Water Costs from the Optimized RO Designs ........ 16

7.4 Summary of Economic Ground Rules and Evaluation of Unit

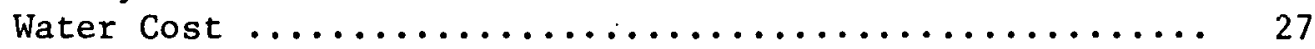

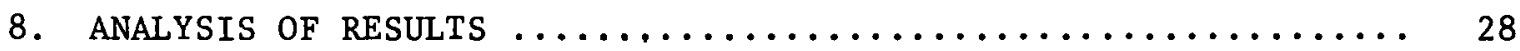

8.1 Range of Capital and Unit water Costs ............. 28

8.2 Effect of Seawater Salinity and Temperature ........... 28

8.3 Effect of System Pressure and Membrane Life ........... 30

8.4 Effect of Energy Cost and Compar1sun with Multistage

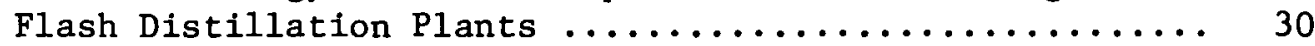

8.5 Overall Sensitivity Analysis of Technological and Cost

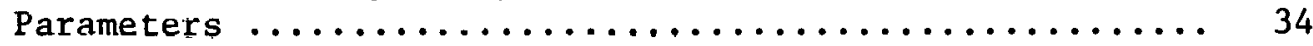

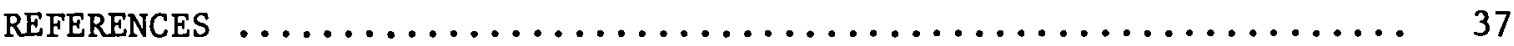

APPENDIX A. Computer Printout of a 2.5-Mgd RO Plant Based on

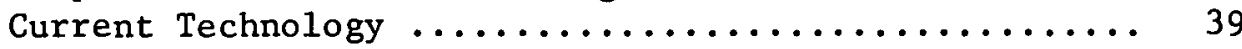

APPENDIX B. Computer Printout of a 2.5-Mgd RO Plant Based on Projected Technolugy ..................... 43

APPENDIX C. Conversion Factors .................... 47 
THIS PAGE

WAS INTENTIONALLY

LEFT BLANK 


\section{ACKNOWLEDGMENT}

The authors gratefully acknowledge the assistance and information suppli.ied by Dr. N. W. Rosenblatt of E. I, duPont deNemour's \& Co. related to the Permasep hollow-fibre permeators. 


\section{PARAMETRIC STUDY AND PRELIMINARY EVALUATION OF REVERSE OSMOSIS FOR SEAWATER DESALINATION}

P. Glueckstern*

S. A. Reed

J. V. Wilson

\section{ABSTRACT}

A parametric study of one- and two-stage reverse osmosis (RO) systems for seawater desalination was made with the aid of a recently developed computer program for optimization of Ro systems. Membrane manufacturer's performance data and predicted cost data were applied. Based on these data and other equipment and operating costs considered, a preliminary evaluation of the economics of RO for seawater desalination was made. Plant capacities in the range of 1 to $12.5 \mathrm{Mgd}$ were considered and compared economically with the current most common multistage flash distillation process at different energy price levels.

\section{INTRODUCTION}

Recently the reverse osmosis (RO) process, which is now most commonly applied for quality improvement of brackish water, has also become a potential contender for seawater desalting. The RO process may be attractive for small plant capacities, especially when the dual-purpose electric power-seawater desalting cannot be applied. For this situation, the less energy consuming RO process is becoming more and more attractive, as energy costs continue to increase.

Although RO membranes for seawater conversion have been demonstrated at several locations, in the last two years, this technology is not yet fully commercial and cannot be considered as "proven technology." This is due to several operational uncertainties which strongly affect the economics of the process, namely, membrane life and the required raw seawater pretreatment. These factors are affected primarily by the quality of the raw seawater and the developmental status of membrane technology.

*Currently Head of Desalting Department, Mekoroth Water Co., Tel Aviv, Tsrael. 
No detailed economic evaluation of the RO process for seawater desalination has been published. Most of the available data concerning economics was published by membrane manufacturers involved in developing membranes for seawater application. Usually, only overall figures predicting the cost for "projected technology" were stated. Using this type of information, a preliminary cost study employing thin film cellulose triacetate membranes, was published recently. ${ }^{1}$

The main objective of the present investigation was to perform a parametric study to identify the interaction between the various operational and economic parameters, and to make a preliminary evaluation of the economics of RO for seawater desalination for a reasonable set of operational and economic assumptions. This investigation includes much more detailed cost information than other previously published cost estimates. 


\section{SUMMARY AND CONCLUSIONS}

This investigation was basically a parametric study of "nearcommercial" RO technology for seawater desalination. Based on performance data obtained from membrane manufacturers and various technological and economical assumptions, optimal systems were designed and evaluated economically for several plant sizes in the 1- to 12.5-Mgd range.

As detailed membrane performance data (as a function of the operating parameters) were obtained only for hollow-fibre aromatic polyamide membranes, the parametric study was based mainly on this membrane technology. Currently, the largest module size ( $8 \mathrm{in}$. diam) at reference operating conditions $\left(800 \mathrm{psig}, 25^{\circ} \mathrm{C}\left(77^{\circ} \mathrm{F}\right), 30 \%\right.$ recovery and a feed salinity of $30,000 \mathrm{ppm} \mathrm{NaC1}$ ) has a productivity of $5000 \mathrm{gpd}$ and a salt rejection of 98.5\%. The assumed costs of these modules (termed "current technology") were $\$ 0.75 /$ gpd ( $\$ 3750 /$ module) for initial cost including housing, and $\$ 0.60 / g p d$ for replacement membranes.

In order to evaluate the effect of predicted near-term developments (termed "projected technology"), a 12-in. module with a productivity of $10,000 \mathrm{gpd}$ (at reference operating conditions) has been assumed to cost $\$ 0.50 /$ gpd initial cost and $\$ 0.40 /$ gpd membrane replacement cost.

The bases for evaluating the capital costs of the various optimized RO systems were as follows:

1. Direct costs of basic Ro equipment:

- Initial membrane module costs: Unit costs (\$/gpd at reference operating conditions) as mentioned above.

- Other standard RO equipment cost (pumps, piping, instrumentation etc.): Detailed cost functions based on conceptual designs of brackish water RO systems adapted to two-stage seawater RO systems and escalated to First Quarter 1976 prices. ${ }^{2}$

2. Site and pretreated seawater supply:

- Site and supply of raw seawater; Cost functions applied to ORNL's computer programs for seawater distillation processes.

- Raw seawater pretreatment system: Updated cost of equipment recommended by Ralph Stone and Co. Inc., based upon the findings of the Chula Vista, California, Pilot Plant Testing program to evaluate seawater pretreatment methods (OSW Report No. 890). ${ }^{3}$ 
3. Indirect capital cost and contingency:

- Engineering, design and supervision; interest during construction; escalation during construction and owner's cost for training and start up: Cost functions applied in ORNL's computer programs for seawater distillation processes assuming a $10 \%$ interest rate and a $8 \%$ annual escalation rate.

- Contingency: $15 \%$ of all direct and indirect capital costs. For "open ocean" seawater with a salinity of $3.5 \%$ and an average feed temperature of $25^{\circ} \mathrm{C}\left(77^{\circ} \mathrm{F}\right)$, the resulting capital costs for optimized two-stage systems were as follows:

$$
\text { (\$/gpd) }
$$

\begin{tabular}{|c|c|}
\hline $\begin{array}{l}1.0 \mathrm{Mgd} \\
\text { systems }\end{array}$ & $\begin{array}{l}12.5 \mathrm{Mgd} \\
\text { systems }\end{array}$ \\
\hline
\end{tabular}

(a) For current technology:

\begin{tabular}{|c|c|c|}
\hline $\begin{array}{l}\text { Basic RO equipment } \\
\text { Site, seawater intake \& pretreatment } \\
\text { Indirect capital \& contingency }\end{array}$ & $\begin{array}{l}2.16 \\
1.14 \\
1.91\end{array}$ & $\begin{array}{l}1.94 \\
0.56 \\
1.53\end{array}$ \\
\hline $\begin{array}{l}\text { Total without power recovery } \\
\text { turbine }\end{array}$ & 5.21 & 4.03 \\
\hline $\begin{array}{l}\text { Power recovery turbine } \\
\text { (including indirect costs) }\end{array}$ & $\underline{0.22}$ & 0.05 \\
\hline $\begin{array}{l}\text { Total with power recovery turbine } \\
\text { For projected technology: }\end{array}$ & 5.43 & 4.08 \\
\hline $\begin{array}{l}\text { Basic RO equipment } \\
\text { Site, seawater intake \& pretreatment } \\
\text { Indirect capital and contingency }\end{array}$ & $\begin{array}{l}1.60 \\
0.99 \\
1.49\end{array}$ & $\begin{array}{l}1.28 \\
0.50 \\
1.07\end{array}$ \\
\hline $\begin{array}{l}\text { Total without power recovery } \\
\text { turbine }\end{array}$ & 4.08 & 2.85 \\
\hline $\begin{array}{l}\text { Power recovery turbine } \\
\text { (including indirect costs) }\end{array}$ & 0.19 & 0.04 \\
\hline Total with power recovery turbine & 4.27 & 2.89 \\
\hline
\end{tabular}

It is noted that the resulting capital cost is approximately twice as much as the figures recently estimated by membrane manufactures. The major factors for the higher estimated costs in this study were the more conservative assumptions regarding long-term membrane performance (log flux decline), materials of construction and standby equipment, higher 
cost for site and pretreated seawater supply and the much higher allowance for indirect costs and contingency (usually underestimated if applied at all by membrane manufacturers). Obviously, a meaningfull comparison can only be made by applying identical ground rules concerning site development, seawater intake, pretreatment and indirect capital cost items. The assumptions made in the current study (excluding pretreatment) were identical to those made in the evaluation of current technology seawater distillation process, recently made at the Oak Ridge National Laboratory (ORNL), so that a comparative analysis can be made on an objective basis.

By comparing the capital cost of a 1-Mgd RO seawater desalination plant with that of a 1-Mgd multistage.flash (MSF) plant, it was found that the capital cost of the Ro plant based on current technology is approximately the same as that of an MSF plant with a performance ratio of $13.4 \mathrm{lb} / 1000 \mathrm{Btu}$ (optimized for high energy cost). The cost of an Ro plant based on projected technology would, however, be approximately $20 \%$ lower.

The resulting unit water costs, calculated for a $10 \%$ interest rate, $85 \%$ plant factor and a $\$ 0.020 / \mathrm{kWhr}$ electricity cost, were as follows:

(\$/kgal)

\begin{tabular}{|c|c|c|}
\hline & $\begin{array}{l}1.0-\mathrm{Mgd} \\
\text { systems }\end{array}$ & $\begin{array}{l}12.5-\mathrm{Mgd} \\
\text { systems }\end{array}$ \\
\hline For current technology & 4.70 & 3.90 \\
\hline For projected technology & 3.30 & 2.50 \\
\hline
\end{tabular}

The long-term membrane performance factors which must be realized in order to obtain the above costs are a membrane life of 2 years and $10 \mathrm{~g}$ flux decline of 0.05 for current technology, and a membrane life of 3 years and a log flux decline of 0.03 for projected technology.

It should be emphasized that the unit water cost is very sensitive to those not yet fully proven (even the current technology assumptions) membrane performance factors. On the other hand, the assumed operating pressure (800 psig), as well as other operating and performance factors, are based on a rather conservative approach. After some further development, it is probable that capital and unit water costs will eventually be lower than those obtained for projected technology. The results of a 
sensitivity analysis made for a $12.5 \mathrm{Mgd}$ system indicated that a set of optimistic operational and costing assumptions would, if realized, eventually reduce unit water cost to approximately $\$ 1.50 / \mathrm{kgal}$, compared to approximately $\$ 2.50 / \mathrm{kgal}$ obtained for projected technology based on a conservative approach. It is, however, questionable if optimistic assumptions such as higher operating pressures and longer membrane life can be realized simultaneously.

One of the most attractive features of the RO process, in comparison to distillation processes, is obviously its lower energy requirement. RO systems are therefore considerably less sensitive to energy price fluctuations. The comparison made with single- and dual-purpose MSF plants indicated that current technology Ro systems can compete with singlepurpose plants in the 1-Mgd size at locations with prevailing high energy costs, while projected technology RO systems are not realistically competitive with small MSF dual-purpose plants in the 1.0- to 2.5-Mgd range.

The unit water costs from the Ro systems evaluated were found to be considerably less sensitive to energy price levels than other desalting processes. A comparison made with single- and dual-purpose multistage flash distillation (MSF) plants indicated that RO systems, at the present stage of technology, might eventually be competitive with single-purpose MSF plants in the 1-Mgd range at locations with prevailing high energy costs.

The development potential of RO technology for seawater desalination was analyzed by making several basic assumptions for an improved 12-1n.diameter module with extrapolated initial performance data based on the current-technology 8-in. module. The basic assumptions for this module termed "projected technology" were: (a) a unit membrane cost decrease from. $\$ 0.75$ to $\$ 0.50 /$ gpd, (b) a projected membrane life of 3 instead of 2 years, and (c) a lower log flux decline factor of 0.03 rather than 0.05 . If these assumptions could be realized, the unit water cost would be decreased by about 30 to $35 \%$. In this case, Ro technology is nut realistically competitive with small MSF dual-purpose plants in the 1-25 Mgd range at locations even with prevailing high fuel costs. 


\section{SCOPE AND OBJECTIVES}

The objectives of the present study were as follows:

1. To identify the interaction between operational and economical parameters of the RO process for seawater desalination.

2. To make a preliminary evaluation of the economics of the Ro. process for a reasonable set of operational and economical assumptions.

3. To compare the potential economics of the RO process with the most commonly used multistage flash distillation process, at various site and economic conditions.

The study was based on performance data obtained from membrane manufacturers. Most of the data were obtained for hollow-fibre polyamid membranes. The parametric study considered, mainly, this membrane type. The effects of most operational parameters, such as system pressure, feed temperature and product recovery on membrane performance, would probably not be very different for other types of seawater Ro membranes having similar salt rejection properties. Most of the results of the parametric study can therefore be considered indicative for the Ro process in general.

The economic evaluation considered plant capacities in the range of 1.0 to $12.5 \mathrm{Mgd}$.

The parametric study considered the following range of feed, operational, and economic variables:

$\begin{array}{ll}\text { Feed salinity } & 25,000-45,000 \mathrm{ppm} \\ \text { Feed temperature } & 18-35^{\circ} \mathrm{C}\left(65-95^{\circ} \mathrm{F}\right) \\ \text { First stage pressure } & 750-1000 \mathrm{psi} \\ \text { First stage product recovery } & 10-50 \% \\ \text { Second stage product recovery } & 50-90 \% \\ \text { Membrane life } & 1-5 \text { years } \\ \text { Log flux decline } & 0.02-0.05 / \mathrm{m} / \\ \text { Electrical power cost } & 0.02-0.05(\$ / \mathrm{kWh}) \\ \text { Independently operating train sizes } & 0.5-1.25 \mathrm{Mgd} \\ \text { Membrane module sizes* } & 5000 \text { and } 10,000 \mathrm{gpd} \\ \text { Unit membrane costs* } & \\ \quad & \\ \text { First stage initial cost } & 0.75 \text { and } 0.50(\$ / \mathrm{gpd}) \\ \text { First stage replacement cost } & 0.50 \text { and } 0.40(\$ / \mathrm{gpd}) \\ \text { Second stage initial cost } & 0.20 \text { and } 0.15(\$ / \mathrm{gpd}) \\ \text { Second stage replacement cost } & 0.15 \text { and } 0.10(\$ / \mathrm{gpd})\end{array}$

*At reference operating conditions defined by the manufacturer. 


\section{EVALUATION METHOD}

The study was performed with the aid of the computer program $\mathrm{RO}-75,{ }^{2}$ developed at ORNL. This program was aimed at optimizing RO systems applying defined membrane technology, by varying the operational parameters, such as system pressure, feed temperature and product recovery in a range defined by the membrane manufacturers. For each specific requirement of plant capacity and product quality, R0-75 defines a reference design based on the applied membrane performance data. This reference design will apply (optionally, upon request) to a two- or one-stage membrane system, provided the rejection rate of the applied membrane is high enough, and can include, or not include, a power recovery turbine generator set. The capital cost of the reference design was then evaluated by applying appropriate cost functions to all required site work (buildings, seawater intake and outfall, etc.) and all other process equipment, including pumps and drivers, valves, piping, instrumentation, electrical equipment, pre- and posttreatment systems and the power recovery turbines (if used). The cost of the membrane modules is computed by multiplying the number of required modules and the assumed cost per module. The unit water cost corresponding to this design is then evaluated on the basis of a defined set of operational and economic ground rules (see Sects, 5 and 6 ).

The reference designs were optimized (with the aid of a special subroutine included in $\mathrm{RO}-75)$, by varying the operational parameters in a defined range. On the basis of the cost data obtained, only the recovery ratios of the first stage and, if applicable, a second stage, could be optimized. 


\section{RO PLANT CONCEPTS EVALUATED}

\subsection{Process Description and Basic Assumptions}

The schematic flow diagram of the RO plants which were evaluated is shown in Fig. 1. The inlet feed was assumed to come from seawater wells for small plant capacities (up to $5 \mathrm{Mgd}$ ) and via a submarine line for larger plant capacities. The raw seawater is pumped to a pretreatment system, which has to be designed in accordance with raw seawater quality and the membrane technology. In the present evaluation the pretreatment system, recommended in OSW Research and Development Progress Report No. 890,3 has been adopted. This pretreatment includes chlorination (10 ppm Cl $\mathrm{Cl}_{2}$ ), detention (40 min), sand filtration $\left(2.36 \mathrm{gpm} / \mathrm{ft}^{2}\right.$ ), and activated carbon filtration $\left(4.60 \mathrm{gpm} / \mathrm{ft}^{2}\right)$.

In addition to the equipment required to remove organic material and residual chlorine, and to reduce the turbidity level below 1 JTU,* an acid injection system for $\mathrm{pH}$ adjustment (to prevent calcium carbonate precipitation and hydrolysis in the case of celulose acetate membranes) and micron filter cartridges ( 5 microns for hollow-fibre membranes) were included. From the pretreatment system the treated feed is pumped by centrifugal pumping units to a number of trains composed of parallel (and optionally tapered) RO modules. Reference train sizes of 0.5 to 1.25 Mgd were considered. The outcoming permeate, or product water, is transferred to a storage tank and the concentrated brine is rejected to the outfall system or optionally via a power recovery turbine.

For two-stage systems, a part or all of the permeate produced by the first stage is pumped by the second-stage high-pressure feed pumps through the second stage Ro modules, arranged in one or more trains. The rejected brine from the second stage, which is usually at lower salinity than the incoming seawater, is recycled to the inlet of the first stage while the permeate is transferred to the posttreatment system. This system consists of a decarbonating tower and a neutralizing agent (caustic or soda-ash) feeder. Finally, the treated product is pumped by one, or more, pumping units to the water supply system.

*Jackson turbidity units. 


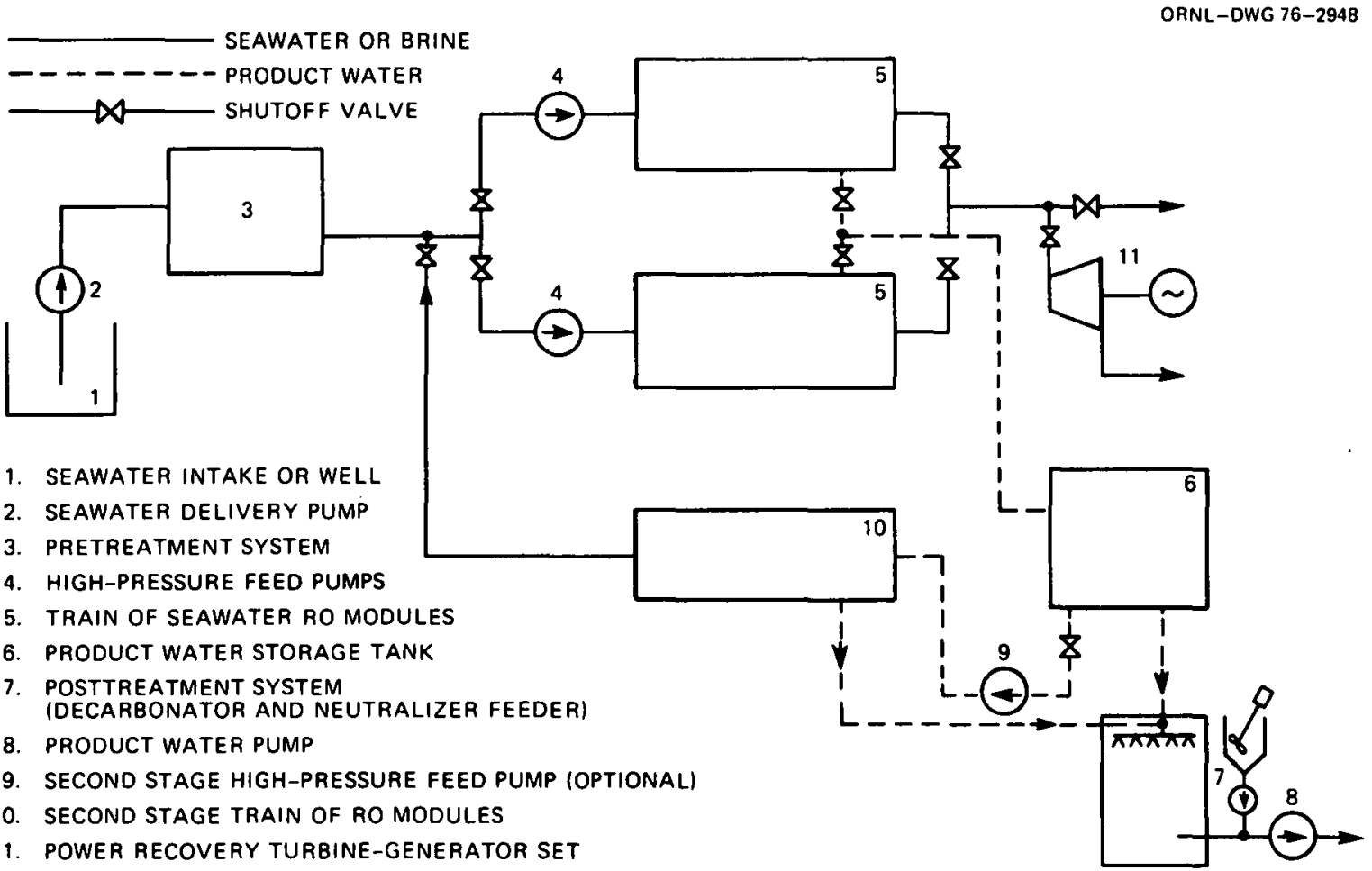

Fig. 1. Schematic diagram of reverse osmosis plant. 


\subsection{Basic Design Criteria}

As discussed in the previous sections the present evaluation was based on actual membrane performance data for specified modules which have been published by membrane manufacturers. These data as well as the basic criteria of the associated process equipment on which the evaluation has been based are summarized in Table 1 .

Table 1. Summary of basic design criteria

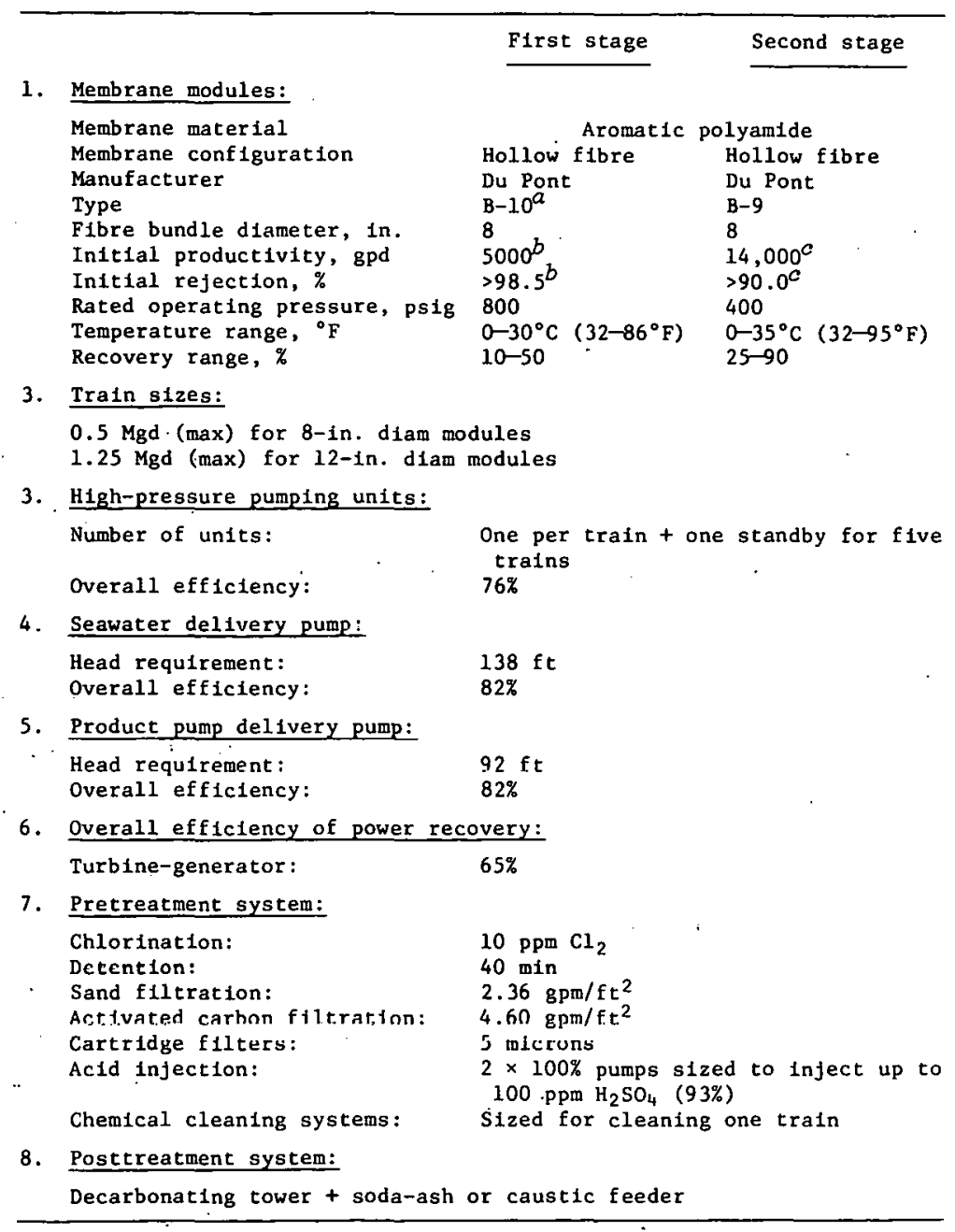

$a_{\text {The }} 8 \mathrm{in}$. B-10 is not yet commercial and the cited performance data was based on Ref. 4 and extrapolation of the commercial 4 in. B-10. For "projected technology" a 12-in. module having the same basic characteristics has been assumed.

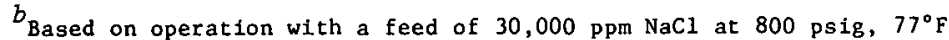
and $30 \%$ recovery:

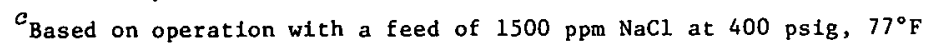
and $75 \%$ recovery. 


\section{ECONOMIC GROUND RULES}

\subsection{Bases for Estimating the Direct Capital Cost}

Two seawater membrane module costs, including housing, were assumed. A cost of $\$ 0.75$ per gpd was assumed for current technology 8-in.-diam modules and $\$ 0.50$ per gpd for projected technology 12-in.-diam modules. These unit costs correspond to the reference productivity rates defined in Table 1. Similarly, two different cost values were assumed for the second stage membrane modules; a unit cost of $\$ 0.20$ per gpd for current technology 8-in.-diam brackish water modules and a unit cost of $\$ 0.15$ for projected technology 12-in.-diam brackish water modules.

The costs of high-pressure pumping units were based on a cost function presented in Ref. 5, escalated to First Quarter 1976 prices. The costs of other pumping units were evaluated with cost functions applied in ORNL's computer programs MSF $21^{6}$ and VTE $21^{7}$ escalated to First Quarter 1976 prices. ${ }^{8}$

The costs of power recovery turbines were based on equipment cost functions published in OSW Research and Development Report No. $457^{9}$ escalated to First Quarter $19 \overline{7} 6$ prices. A $100 \%$ additional cost was applied for mechanical and electrical installations.

The costs of seawater intake and outfall systems and that of the product water posttreatment systems were calculated on the basis of cost data applied in ORNL's computer programs VTE21 and MSF21. However, for small plant capacities, it was assumed that seawater wells will be cheaper than a long submarine intake by about $20 \%$.

The capital costs of valves and piping, electrical equipment, and instrumentation were based on cost data from the Fluor study for the OSW, 10 downscaled to smaller size trains and escalated to First Quarter 1976 prices.

The cost of site development was based on cost functions published in Ref. 10. For buildings, a unit cost of $\$ 16.50 / \mathrm{ft}^{2}$ was used.

The pretreatment system, as already discussed in Sect. 5, utilized equipment recommended in OSW Report No. $890 .{ }^{3}$ The capital cost for this equipment was upscaled to the capacities required by applying a scale factor of 0.7 and escalated to First Quarter 1976 prices. 


\subsection{Bases for Estimating Indirect Capital and Total Annualized Capital Costs}

The indirect capital costs included the following components:

(a) Engineering design and supervision.

(b) Escalation during construction.

(c) Interest during construction.

(d) Owner cost for training and startup.

The first three components were calculated by the same cost function applied in the evaluation of distillation plants, 11 by applying an escalation rate of $8 \%$ and an interest rate of $10 \%$. The owner costs were assumed to be $1.9 \%$ of the total direct and indirect capital costs. Finally, a contingency of $15 \%$ on all capital (direct + indirect) costs was applied to estimate the total investment.

The total annualized capital costs were calculated on the basis of the following economic ground rules:

- interest rate: $10 \%$

- sinking fund depreciation rate based on a 30-year plant life

- insurances and taxes: $1 \%$

\subsection{Bases for Estimating the Operating Costs}

The operating costs included the following components:

(a) Membrane replacement

(b) Electrical power

(c) Operation and maintenance labor

(d) Supplies and maintenance materials

(e) Chemicals

The membrane replacement costs were calculated on the basis of unit membrane replacement cost per gpd, corresponding to the two assumed values of initial membrane cost (including housing), and the assumed membrane life. The latter was evaluated parametrically; however, for the reference designs, lives of 2 and 3 years were assumed for seawater membranes based on current and projected technology, respectively. For the second-stage membranes a 3-year life was assumed for both. The applied unit membrane replacement costs are listed in Table 2. 
Table 2. Summary of economic ground rules and parameters

\begin{tabular}{ll}
\hline Interest rate & $10 \%$ \\
Insurances and taxes & $1 \%$ \\
Plant operating factor & $85 \%$ \\
Equipment cost basis & First Quarter 1976 \\
Plant life & 30 years \\
Electric power cost (reference) & $\$ 0.02 / \mathrm{kWhr}$ \\
Contingency & $15 \%$ \\
Annual escalation of costs during construction & $8 \%$ \\
O\&M labor cost & $\$ 16,000 /$ man-year (av) \\
General and administration cost & $40 \%$ of O\&M labor \\
Annual costs for supplies and materials & $0.7 \%$ of total capital \\
& cost
\end{tabular}

Unit prices of chemicals:

Sulfuric acid

Chlorine

Unit costs of membrane modules:
$\$ 31 /$ ton (bulk, $100 \%$ basis)

$\$ 176 /$ ton

\begin{tabular}{cl}
$\begin{array}{cl}\text { Current } & \text { Projected } \\
\text { technology } & \text { technology }\end{array}$ \\
\hline
\end{tabular}
Initial costs, \$/gpd
First stage
0.75
0.50
Second stage
0.20
0.15
Replacement cost, \$/gpd

$\begin{array}{lll}\text { First stage } & 0.60 & 0.40 \\ \text { Second stage } & 0.15 & 0.10\end{array}$
Membrane life, years
First stage
23
Second stage
33
Log flux decline, /m/
0.05
0.03 
For the electrical power cost, a range of $\$ 0.02$ to $\$ 0.05 / \mathrm{kWhr}$ was used. The reference designs however were optimized for an assumed power cost of $\$ 0.02 / \mathrm{kWhr}$.

The annual operation and maintenance labor costs of a 1-Mgd plant were calculated on the basis of 5 men at an average cost of $\$ 16,000 / \mathrm{man}-$ year, with an additional general and administration cost of $40 \%$ of direct labor cost. For larger plants a scale factor of 0.5 was applied.

The annual costs for supplies and maintenance materials were assumed to be $0,7 \%$ of the total capital costs.

The annual costs for chemicals were based on the specific consumptions listed in Table 1 and the unit. costs of chemicals 1 isted in Table 2 . An allowance of $\$ 0.05$ per 1000 gallons of product water was made for chemical cleaning of the membranes. 


\section{RESULTS FOR OPTIMIZED RO SYSTEMS}

\subsection{Optimum Product Recovery and Other Design Data}

The resulting optimum product recovery ratios versus electric power cost, plant capacity, feed salinity and membrane cost, for systems with and without power recovery, are summarized in Table 3 .

Typical design characteristics of two-stage systems applying 8 in. (current) and $12 \mathrm{in.} \mathrm{(projected)} \mathrm{hollow-fibre,} \mathrm{polyamid,} \mathrm{membrane} \mathrm{modules}$ are presented in Table 4, for 1- and 12.5-Mgd plant capacities. More detailed design data for a 2.5-Mgd plant optimized for an electrical power cost of $\$ 0.05 / \mathrm{kWh}$ is shown in the computer printouts included in the Appendices $A$ and $B$, for plants applying current and projected technology, respectively.

\subsection{Capital Cost of the Optimized RO Designs}

The resulting capital cost versus plant capacity and feed salinity of optimized current technology ( 8 in. membrane modules) and projected technology (12 in. membrane modules) Ro systems applying power recovery are summarized in Table 5 .

A detailed capital cost breakdown for 1- and 12.5-Mgd plant capacities, operating with a feed salinity of $35,000 \mathrm{ppm}$, is presented in Table 6 .

The capital costs versus plant capacity and versus feed salinity are also illustrated in Figs. 2 and 3, respectively.

\subsection{Unit Water Costs from the Optimized Ro Designs}

The resulting unit water costs versus electric power cost, plant capacity, feed salinity and unit membrane cost for systems with and without power recovery are summarized in Table 7 .

A detailed unit water cost breakdown for 1- and 12.5-Mgd plant capacities (for which the capital cost breakdown is given in Table 6) is presented in Table 8 .

The unit water costs versus plant capacity and versus seawater salinity are also illustrated in Figs. 4 and 5, respectively. 
Table 3: Optimum fraction recovery vs electric power cost, plant capacity, feed salinity and membrane $\operatorname{cost}^{a}$

\begin{tabular}{|c|c|c|c|c|c|c|c|c|}
\hline \multirow{3}{*}{$\begin{array}{l}\text { Power cost, } \$ / \mathrm{kWhr} \\
\text { Power recovery } \\
\text { Plant capacity, } \mathrm{m}^{3} / \mathrm{d} \\
(\mathrm{Mgd})\end{array}$} & \multicolumn{4}{|c|}{0.02} & \multicolumn{4}{|c|}{0.05} \\
\hline & \multicolumn{2}{|c|}{ Yes } & \multicolumn{2}{|c|}{ No } & \multicolumn{2}{|c|}{ Yes } & \multicolumn{2}{|c|}{ No } \\
\hline & $\begin{array}{l}3785 \\
1.0\end{array}$ & $\begin{array}{c}47,318 \\
12.5\end{array}$ & $\begin{array}{l}3785 \\
1.0\end{array}$ & $\begin{array}{c}47,318 \\
12.5\end{array}$ & $\begin{array}{l}3785 \\
1.0\end{array}$ & $\begin{array}{c}47,318 \\
12.5\end{array}$ & $\begin{array}{l}3785 \\
1.0\end{array}$ & $\begin{array}{c}47,318 \\
12.5\end{array}$ \\
\hline & & & & High mem & ane cos & & & \\
\hline \multicolumn{9}{|l|}{ Feed salinity: ppm } \\
\hline $\begin{array}{l}25,000 \\
30,000 \\
35,000 \\
40,000 \\
45,000\end{array}$ & $\begin{array}{l}0.45 \\
0.35 \\
0.27 \\
0.22 \\
0.19\end{array}$ & $\begin{array}{l}0.40 \\
0.33 \\
0.25 \\
0.23 \\
0.18\end{array}$ & $\begin{array}{l}0.44 \\
0.35 \\
0.29 \\
0.25 \\
0.20\end{array}$ & $\begin{array}{l}0.42 \\
0.34 \\
0.27 \\
0.23 \\
0.19\end{array}$ & $\begin{array}{l}0.46 \\
0.35 \\
0.30 \\
0.26 \\
0.21\end{array}$ & $\begin{array}{l}0.44 \\
0.35 \\
0.29 \\
0.25 \\
0.21\end{array}$ & $\begin{array}{l}0.50^{b} \\
0.35 \\
0.32 \\
0.28 \\
0.23\end{array}$ & $\begin{array}{l}0.48 \\
0.35 \\
0.31 \\
0.27 \\
0.22\end{array}$ \\
\hline & \multicolumn{8}{|c|}{ Low membrane cost ${ }^{c}$} \\
\hline \multicolumn{9}{|l|}{ Feed salinity, ppm } \\
\hline $\begin{array}{l}25,000 \\
30,000 \\
35,000 \\
40,000 \\
45,000\end{array}$ & $\begin{array}{l}0.48 \\
0.35 \\
0.35 \\
0.29 \\
0.23\end{array}$ & $\begin{array}{l}0.47 \\
0.35 \\
0.30 \\
0.27 \\
0.22\end{array}$ & $\begin{array}{l}0.48 \\
0.39 \\
0.34 \\
0.30 \\
0.25\end{array}$ & $\begin{array}{l}0.50^{b} \\
0.36 \\
0.33 \\
0.38 \\
0.23\end{array}$ & $\begin{array}{l}0.50^{b} \\
0.40 \\
0.34 \\
0.30 \\
0.27\end{array}$ & $\begin{array}{l}0.50^{b} \\
0.37 \\
0.34 \\
0.29 \\
0.25\end{array}$ & $\begin{array}{l}0.50^{b} \\
0.42 \\
0.39 \\
0.32 \\
0.27\end{array}$ & $\begin{array}{l}0.50^{b} \\
0.41 \\
0.36 \\
0.31 \\
0.27\end{array}$ \\
\hline
\end{tabular}

$a_{\text {Optimized for conditions defined in Table } 1 .}$

$b$ One-stage design.

$c_{\text {See Table } 2 \text {. }}$ 
Table 4. Major design characteristics of RO systems for seawater desalination ${ }^{a}$

Membrane type: hollow-fibre-aromatic polyamide

System pressure: 800 psig (first stage); 400 psig (second stage)

Feed parameters: temperature $\left(25^{\circ} \mathrm{C}\right)$; salinity $(35,000 \mathrm{ppm})$

\begin{tabular}{|c|c|c|c|c|}
\hline \multirow{2}{*}{$\begin{array}{l}\text { Membrane module diameter } \\
\text { Plant capacity, Mgd }\end{array}$} & \multicolumn{2}{|c|}{8 in. } & \multicolumn{2}{|c|}{12 in. } \\
\hline & 1.0 & 12.5 & 1.0 & 12.5 \\
\hline \multicolumn{5}{|l|}{ Number of trains } \\
\hline $\begin{array}{l}\text { First stage } \\
\text { Second stage }\end{array}$ & $\begin{array}{l}2 \\
1\end{array}$ & $\begin{array}{r}25 \\
5\end{array}$ & $\begin{array}{l}1 \\
1\end{array}$ & $\begin{array}{r}10 \\
2\end{array}$ \\
\hline \multicolumn{5}{|l|}{ 1. Number of modules } \\
\hline $\begin{array}{l}\text { First stage } \\
\text { Second stage }\end{array}$ & $\begin{array}{l}328 \\
25\end{array}$ & $\begin{array}{l}3962 \\
287\end{array}$ & $\begin{array}{l}173 \\
15\end{array}$ & $\begin{array}{l}1951 \\
173\end{array}$ \\
\hline \multicolumn{5}{|l|}{ 2. Product recovery, \% } \\
\hline $\begin{array}{l}\text { First stage } \\
\text { Second stage }\end{array}$ & $\begin{array}{l}28.1 \\
88.5\end{array}$ & $\begin{array}{l}25.8 \\
90.0\end{array}$ & $\begin{array}{l}36.2 \\
84.4\end{array}$ & $\begin{array}{l}31.2 \\
90.0\end{array}$ \\
\hline \multicolumn{5}{|l|}{ 3. Total production, Mgd } \\
\hline $\begin{array}{l}\text { First stage } \\
\text { Second stage }\end{array}$ & $\begin{array}{l}1.035 \\
0.275\end{array}$ & $\begin{array}{r}12.840 \\
3.070\end{array}$ & $\begin{array}{l}1.070 \\
0.375\end{array}$ & $\begin{array}{r}12.960 \\
4.150\end{array}$ \\
\hline \multicolumn{5}{|l|}{ 4. Product salinity, ppm } \\
\hline $\begin{array}{l}\text { From first stage } \\
\text { From second stage }\end{array}$ & $\begin{array}{l}645 \\
120\end{array}$ & $\begin{array}{l}620 \\
125\end{array}$ & $\begin{array}{l}735 \\
115\end{array}$ & $\begin{array}{l}680 \\
140\end{array}$ \\
\hline \multicolumn{5}{|l|}{ 5. Electric power } \\
\hline $\begin{array}{l}\text { Total installed, } \mathrm{kW} \\
\text { Specific consumption, } \\
\text { kWhr/1000 gal }\end{array}$ & $\begin{array}{l}1315 \\
22.80\end{array}$ & $\begin{array}{l}17,680 \\
24.20\end{array}$ & $\begin{array}{l}1085 \\
19.75\end{array}$ & $\begin{array}{l}15,070 \\
21.25\end{array}$ \\
\hline
\end{tabular}


Table 5. Capital cost ${ }^{a}$ of Ro desalting plants vs unit membrane cost, feed salinity and plant capacity, \$/gpd

\begin{tabular}{|c|c|c|c|c|c|c|c|c|}
\hline \multirow{3}{*}{$\begin{array}{l}\text { Membrane module diameter } \\
\text { Unit membrane cost } \$ / \text { gpd. } \\
\text { Plant capacity, Mgd }\end{array}$} & \multicolumn{4}{|c|}{8 in. } & \multicolumn{4}{|c|}{12 in. } \\
\hline & \multicolumn{4}{|c|}{0.75} & \multicolumn{4}{|c|}{0.50} \\
\hline & 1.0 & 2.5 & 5.0 & 12.5 & 1.0 & 2.5 & 5.0 & 12.5 \\
\hline \multicolumn{9}{|l|}{ Feed salinity, ppm } \\
\hline $\begin{array}{l}25,000 \\
30,000 \\
35,000 \\
40,000 \\
45,000\end{array}$ & $\begin{array}{l}4.00 \\
4.53 \\
5.43 \\
6.41 \\
7.61\end{array}$ & $\begin{array}{l}3.47 \\
3.91 \\
4.71 \\
5.61 \\
6.76\end{array}$ & $\begin{array}{l}3.21 \\
3.63 \\
4.39 \\
5.26 \\
6.40\end{array}$ & $\begin{array}{l}2.97 \\
3.36 \\
4.08 \\
4.94 \\
6.06\end{array}$ & $\begin{array}{l}3.19 \\
3.67 \\
4.27 \\
4.94 \\
5.81\end{array}$ & $\begin{array}{l}2.60 \\
2.98 \\
3.54 \\
4.16 \\
4.94\end{array}$ & $\begin{array}{l}2.33 \\
2.65 \\
3.19 \\
3.77 \\
4.53\end{array}$ & $\begin{array}{l}2.10 \\
2.38 \\
2.89 \\
3.46 \\
4.20\end{array}$ \\
\hline
\end{tabular}

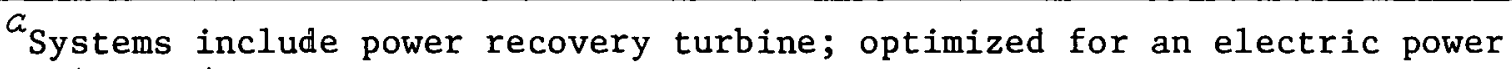
cost of $\$ 0.020 / \mathrm{kWhr}$. 
Table 6. Capital cost breakdown of Ro plants vs unit membrane cost and plant capacity

Membrane type: hollow-fibre-aromatic polyamide

System pressure: 800 psig (first stage); 400 psig (second stage)

Feed parameters: temperature $\left(25^{\circ} \mathrm{C}\right)$; salinity $(35,000 \mathrm{ppm})$

\begin{tabular}{|c|c|c|c|c|c|c|c|c|c|}
\hline \multicolumn{2}{|c|}{ Membrane module diameter } & \multicolumn{4}{|c|}{8 in. } & \multicolumn{4}{|c|}{12 in. } \\
\hline \multicolumn{2}{|c|}{ Unit membrane cost, $\$ / g p d$} & \multicolumn{4}{|c|}{0.75} & \multicolumn{4}{|c|}{0.50} \\
\hline \multirow[t]{2}{*}{ Plant } & \multirow[t]{2}{*}{ capacity, Mgd } & \multicolumn{2}{|c|}{1.0} & \multicolumn{2}{|c|}{12.5} & \multicolumn{2}{|c|}{1.0} & \multicolumn{2}{|c|}{12.5} \\
\hline & & $\$ \times 10^{3}$ & $\%$ & $\$ \times 10^{3}$ & $\%$ & $\$ \times 10^{3}$ & $\%$ & $\$ \times 10^{3}$ & $\%$ \\
\hline I. & Direct capital components & & & & & & & & \\
\hline \multirow[t]{2}{*}{ II. } & Indirect capital components & 1,273 & 36.94 & 12,722 & 40.28 & 999 & 36.82 & 8,876 & 39.40 \\
\hline & Total before contingency & 4,718 & & 44,308 & & 3,710 & & 31,406 & \\
\hline \multirow[t]{2}{*}{ III. } & Contingency & 707 & 20.54 & 6,646 & 21.04 & 557 & 20.52 & 4,711 & 20.91 \\
\hline & Total investment & 5,425 & & 50,954 & & 4,267 & & $36,11.7$ & \\
\hline
\end{tabular}




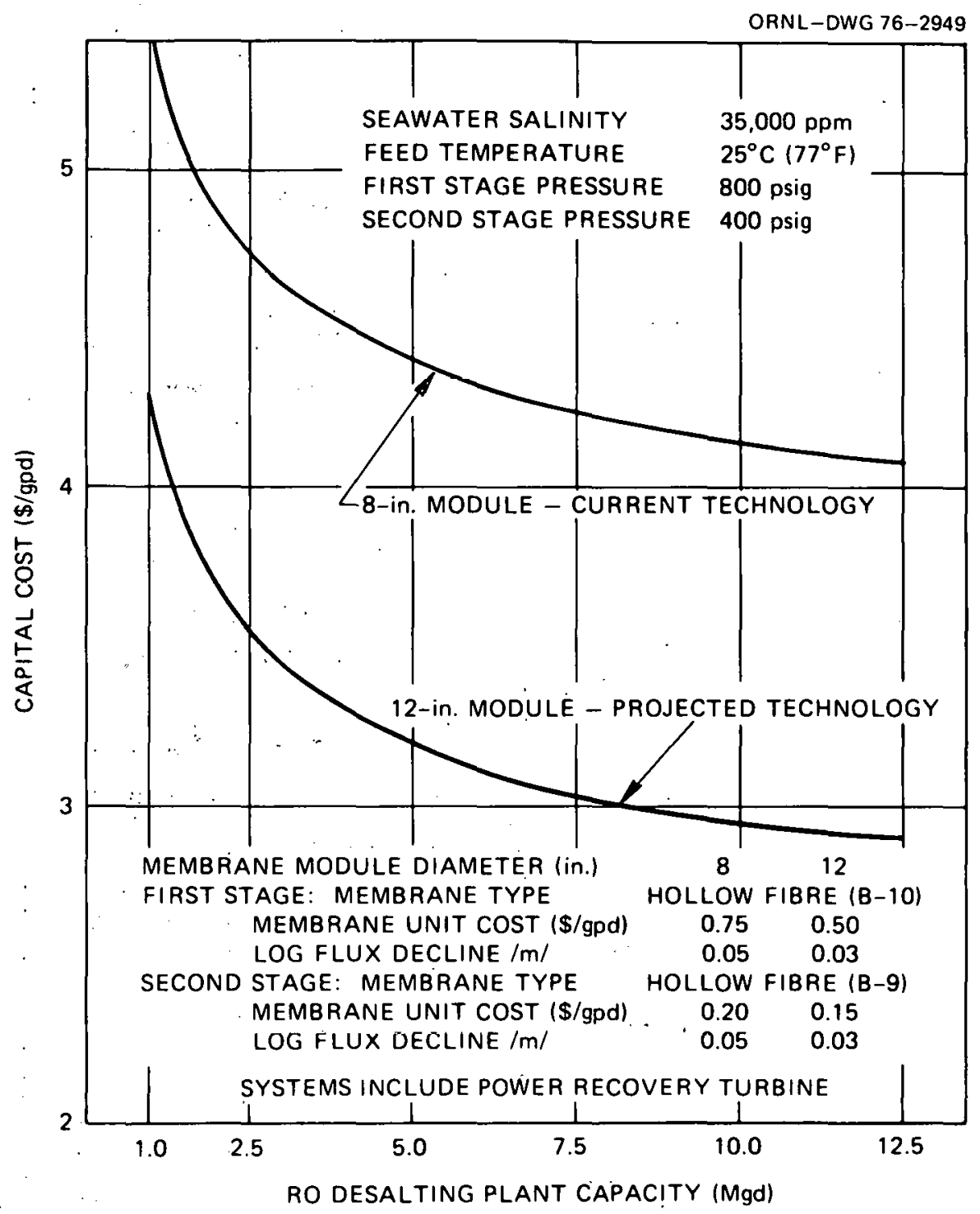

Fig. 2. Capital cost vs reverse osmosis plant capacity. 


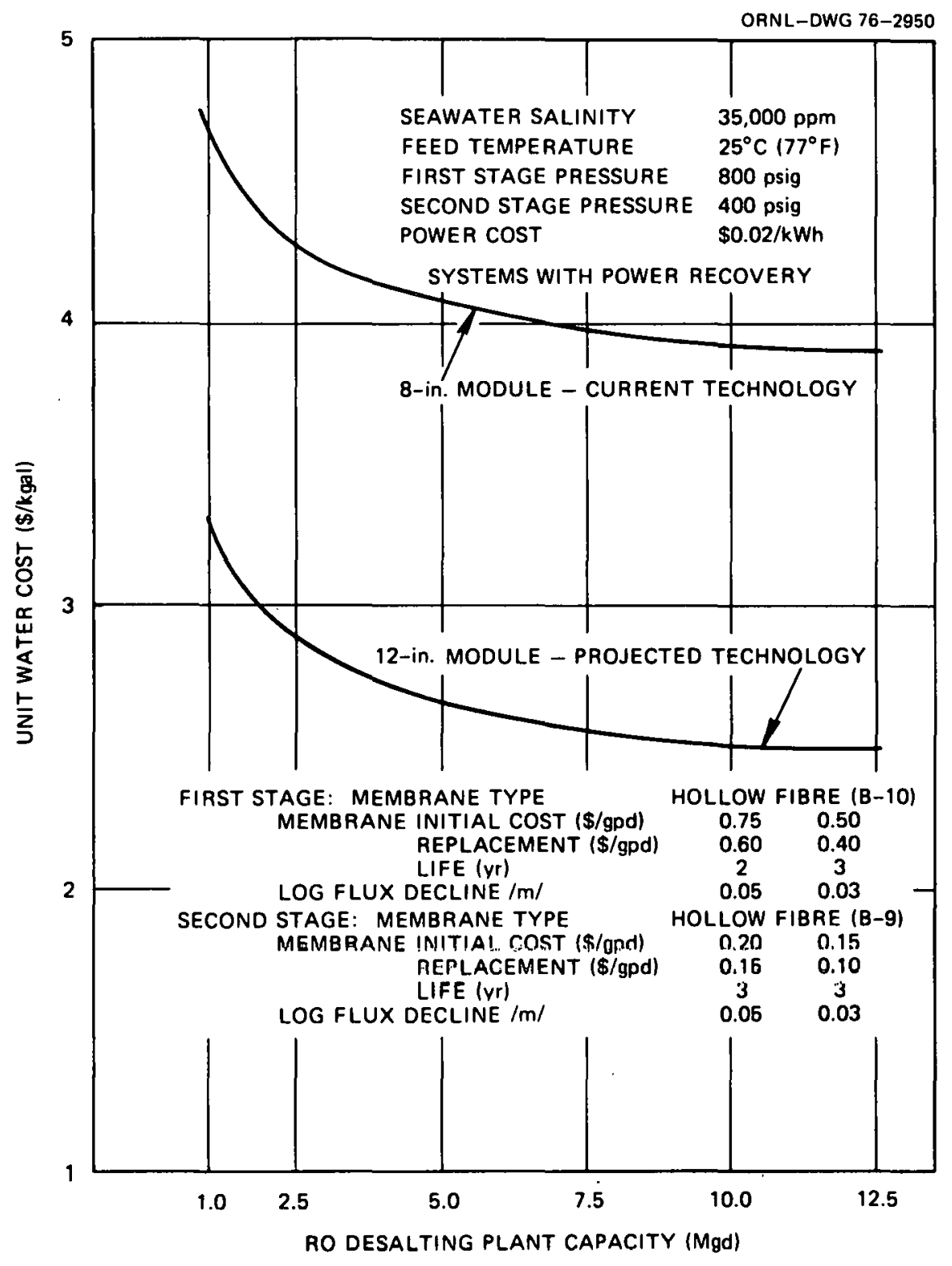

Fig. 3. Unit water cost vs reverse osmosis plant capacity $(35,000 \mathrm{ppm}$ seawater salinity - current and projected technology) 
Table 7. Unit water cost from Ro plants vs electric power cost, plant capacity, feed salinity and membrane cost $(\$ / 1000 \mathrm{gal})^{a}$.

\begin{tabular}{|c|c|c|c|c|c|c|c|c|}
\hline Power cost, $\$ / k W h r$ & \multicolumn{4}{|c|}{0.02} & \multicolumn{4}{|c|}{0.05} \\
\hline \multirow{2}{*}{$\frac{\text { Power recovery }}{\text { Plant capacity, Mgd }}$} & \multicolumn{2}{|c|}{ Yes } & \multicolumn{2}{|c|}{ No } & \multicolumn{2}{|c|}{ Yes: : } & \multicolumn{2}{|c|}{ No } \\
\hline & 1.0 & 12.5 & 1.0 & 12.5 & 1.0 & 12.5 & 1.0 & 12.5 \\
\hline & \multicolumn{8}{|c|}{ High membrane cost } \\
\hline \multicolumn{9}{|l|}{ Feed salinity, ppm } \\
\hline $\begin{array}{l}25,000 \\
30,000 \\
35,000 \\
40,000 \\
45,000\end{array}$ & $\begin{array}{l}3.50 \\
3.90 \\
4.70 \\
5.60 \\
6.75\end{array}$ & $\begin{array}{l}2.80 \\
3.20 \\
3.90 \\
4.75 \\
5.90\end{array}$ & $\begin{array}{l}3.50 \\
3.95 \\
4.80 \\
5.70 \\
6.90\end{array}$ & $\begin{array}{l}2.90 \\
3.30 \\
4.05 \\
4.95 \\
6.75\end{array}$ & $\begin{array}{l}3.95 \\
4.45 \\
5.35 \\
6.35 \\
7.70\end{array}$ & $\begin{array}{l}3.25 \\
3.75 \\
4.60 \\
5.55 \\
6.85\end{array}$ & $\begin{array}{l}4.05^{b} \\
4.70 \\
5.65 \\
6.75 \\
8.75\end{array}$ & $\begin{array}{l}3.45 \\
4.05 \\
4.95 \\
6.00 \\
7.40\end{array}$ \\
\hline & \multicolumn{8}{|c|}{ Low membrane cost } \\
\hline \multicolumn{9}{|l|}{ Feed salinity, ppm } \\
\hline $\begin{array}{l}25,000 \\
30,000 \\
35,000 \\
40,000 \\
45,000\end{array}$ & $\begin{array}{l}2.45 \\
2.80 \\
3.30 \\
3.80 \\
4.50\end{array}$ & $\begin{array}{l}1.80 \\
2.05 \\
2.50 \\
3.00 \\
3.60\end{array}$ & $\begin{array}{l}2.50 \\
2.85 \\
3.35 \\
3.90 \\
4.65\end{array}$ & $\begin{array}{l}1.85^{b} \\
2.15 \\
2.60 \\
3.15 \\
3.80\end{array}$ & $\begin{array}{l}2.90^{b} \\
3.30 \\
3.90 \\
4.50 \\
5.35\end{array}$ & $\begin{array}{l}2.20^{b} \\
2.55 \\
3.10^{\prime} \\
3.70 \\
4.45\end{array}$ & $\begin{array}{l}3.00^{b} \\
3.50 \\
4.10 \\
4.80 \\
5.70\end{array}$ & $\begin{array}{l}2.35^{b} \\
2.80 \\
3.40 \\
4.05 \\
4.90\end{array}$ \\
\hline
\end{tabular}

$a_{\text {Optimized for conditions defined in Table } 1 .}$

$b$ One-stage design. 
Table 8. Unit water cost breakdown of Ro plants vs unit membrane cost and plant capacity

Membrane type: hollow-fibre-aromatic polyamide

System pressure: 800 psig (first stage); 400 psig (second stage)

Feed parameters: temperature $\left(25^{\circ} \mathrm{C}\right)$; salinity $(35,000 \mathrm{ppm})$; electrical power cost $(\$ 0.02 / \mathrm{kWhr})$

\begin{tabular}{|c|c|c|c|c|c|c|c|c|}
\hline \multirow{2}{*}{$\begin{array}{l}\text { Membrane module diameter } \\
\text { Unit membrane cost, } \$ / \text { gpd }\end{array}$} & \multicolumn{4}{|c|}{8 in. } & \multicolumn{4}{|c|}{12 in. } \\
\hline & \multicolumn{4}{|c|}{0.75} & \multicolumn{4}{|c|}{0.60} \\
\hline Plant capacity, Mgd & \multicolumn{2}{|c|}{1.0} & \multicolumn{2}{|c|}{12.5} & \multicolumn{2}{|c|}{1.0} & \multicolumn{2}{|c|}{12.5} \\
\hline Unit water costs & $\$ / \mathrm{kgal}$ & $\%$ & $\$ / \mathrm{kgal}$ & $\%$ & \$/kgal & $\%$ & \$/kgal & $\%$ \\
\hline 1. Capital & 1.95 & 41.6 & 1.44 & 37.1 & 1.54 & 46.7 & 1.03 & 41.4 \\
\hline 2. Membrane replacement & 1.56 & 33.2 & 1.51 & 38.9 & 0.72 & 21.8 & 0.65 & 26.1 \\
\hline 3. Power cost & 0.46 & 9.8 & 0.48 & 12.4 & 0.39 & 11.8 & 0.42 & 16.9 \\
\hline \multicolumn{9}{|l|}{ 4. Operating cost } \\
\hline Staff & 0.36 & 7.7 & 0.10 & 2.6 & 0.36 & 10.9 & 0.10 & 4.0 \\
\hline Maintenance + supplies & 0.12 & 2.6 & 0.09 & 2.3 & 0.10 & 3.0 & 0.07 & 2.8 \\
\hline Chemicals & 0.24 & 5.1 & 0.26 & 6.7 & 0.19 & 5.8 & 0.22 & 8.8 \\
\hline Total operating & 0.72 & 15.4 & 0.45 & 11.6 & 0.65 & 19.7 & 0.39 & 15.6 \\
\hline Total & 4.69 & 100.0 & 3.88 & 100.0 & 3.30 & 100.0 & 2.49 & 100.0 \\
\hline
\end{tabular}




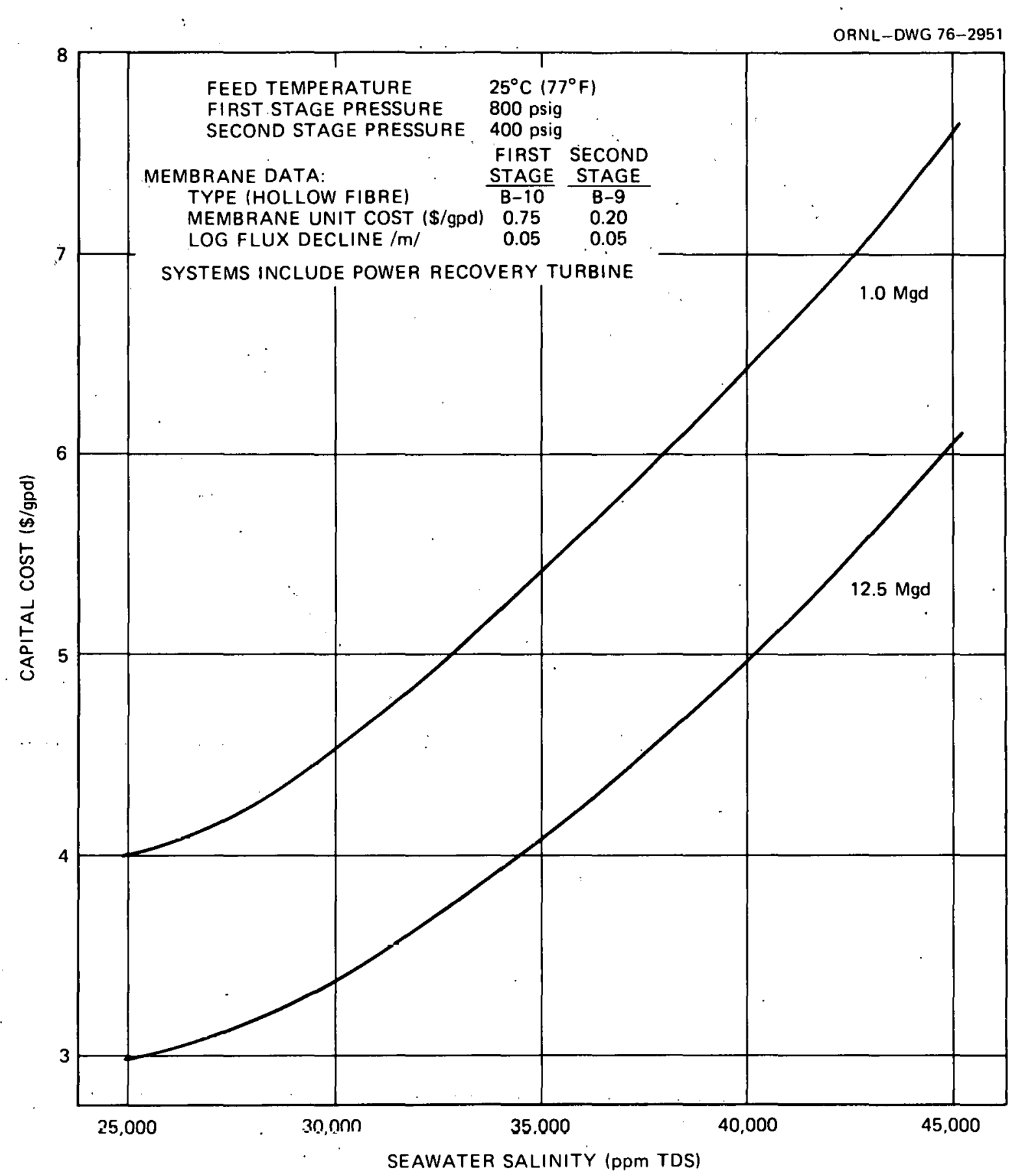

Fig. 4. Capital cost vs seawater salinity and plant capacity current technology. 


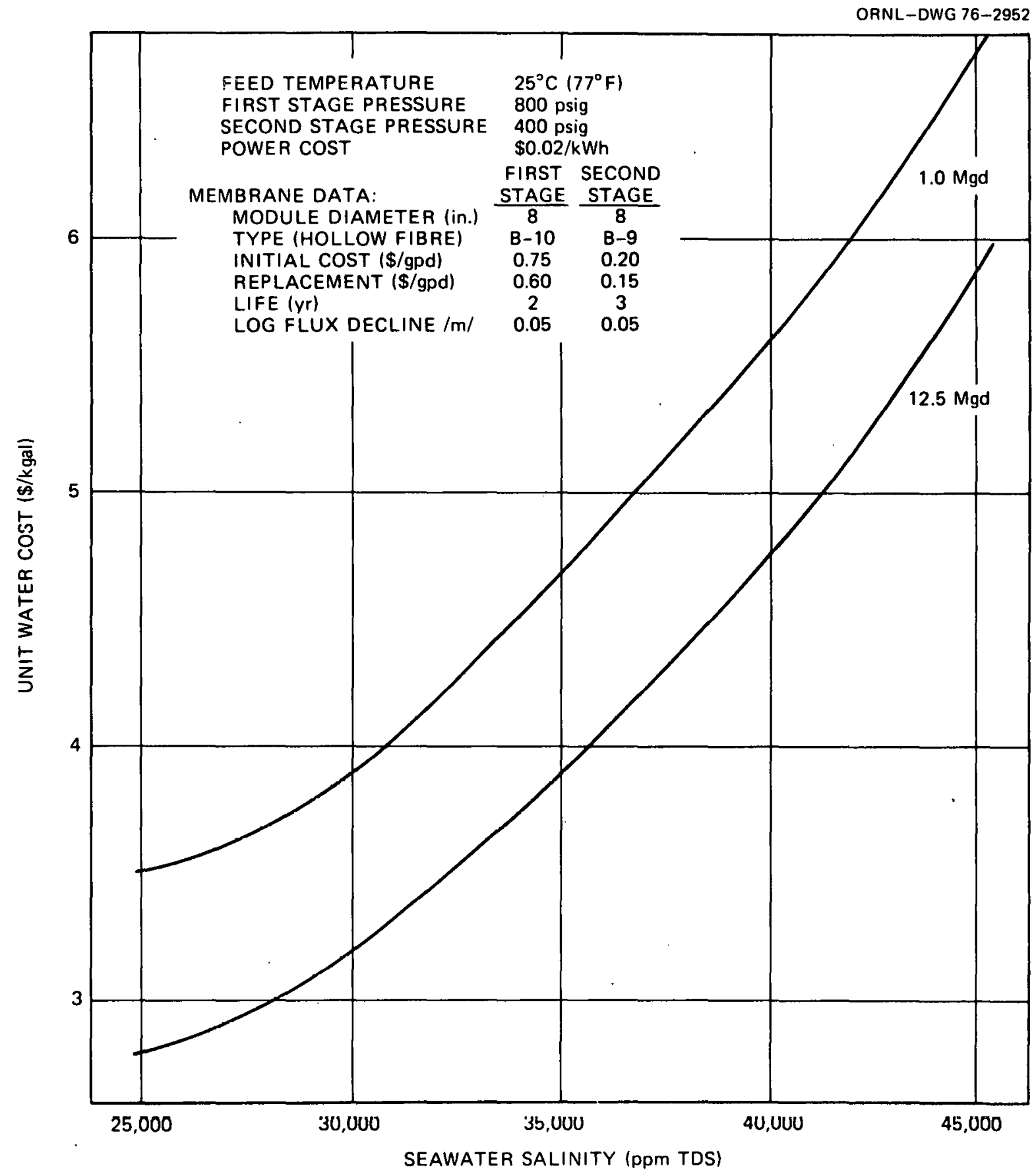

Fig. 5. Unit water cost vs seawater salinity and plant capacity (current technology). 


\title{
7.4 Summary of Economic Ground Rules and Evaluation of Unit Water Cost
}

\begin{abstract}
All annual operating costs and the corresponding unit water costs were based on a plant operating factor of $85 \%$. A summary of the applied economic ground rules is presented in Table 2.
\end{abstract}




\section{ANALYSIS OF RESULTS}

\subsection{Range of Capital and Unit Water Costs}

For the assumed unit membrane cost of $\$ 0.75 / \mathrm{gpd}$, representing current membrane technology and the other cost data detailed in Sect. 6, the resulting capital costs ranged between approximately $\$ 5.40$ to $\$ 4.10 / \mathrm{gpd}$, for RO plant capacities between 1.0 and $12.5 \mathrm{Mgd}$, respectively. These costs correspond to plants operating with an "open ocean" seawater salinity of $35,000 \mathrm{ppm}$ and a feed temperature of $25^{\circ} \mathrm{C}\left(77^{\circ} \mathrm{F}\right)$. The effect of these site parameters is analyzed in the next subsection.

For the assumed lower unit membrane cost of $\$ 0.50 / \mathrm{gpd}$, representing projected technology and the other potential cost savings made possible by application of larger size membrane modules, the resulting capital costs ranged between approximately $\$ 4.30$ and $\$ 2.90 /$ gpd, for Ro plant capacities of 1.0 to $12.5 \mathrm{Mgd}$.

The corresponding unit water cost, based on the assumed economic ground rules listed in Table 2, ranged between approximately $\$ 4.70$ and $\$ 3.90$ per 1000 gallons for the current technnlngy, and hetween $\$ 3.30$ and $\$ 2.50$ for projected technology.

\subsection{Effect of Seawater Salinity and Temperature}

From the resulting capital costs versus seawater salinity shown in Table 5 and Fig. 3, and the unit water costs in Table 7 and Fig. 5, it is quite evident that the prevailing seawater salinity is one of the keyfactors in determining the competitiveness of the RO process for seawater desalting. The resulting unit water costs for a low seawater salinity of $25,000 \mathrm{ppm}$ were about 25 to $20 \%$ lower, and those for a high seawater salinity (e.g., prevailing in the Red Sea) of 45,000 ppm, were about 40 to $50 \%$ higher than those obtained with reference salinity of $35,000 \mathrm{ppm}$ water.

The effect of feed temperature on unit water cost is illustrated in Fig. 6. In the range of $18-30^{\circ} \mathrm{C}\left(65-86^{\circ} \mathrm{F}\right)$, the cost with feed at $30^{\circ} \mathrm{C}$ is about $19 \%$ lower than that obtained with low temperature feed of $18^{\circ} \mathrm{C}$. The corresponding change per degree centigrade is in the order of $1.5 \%$, 


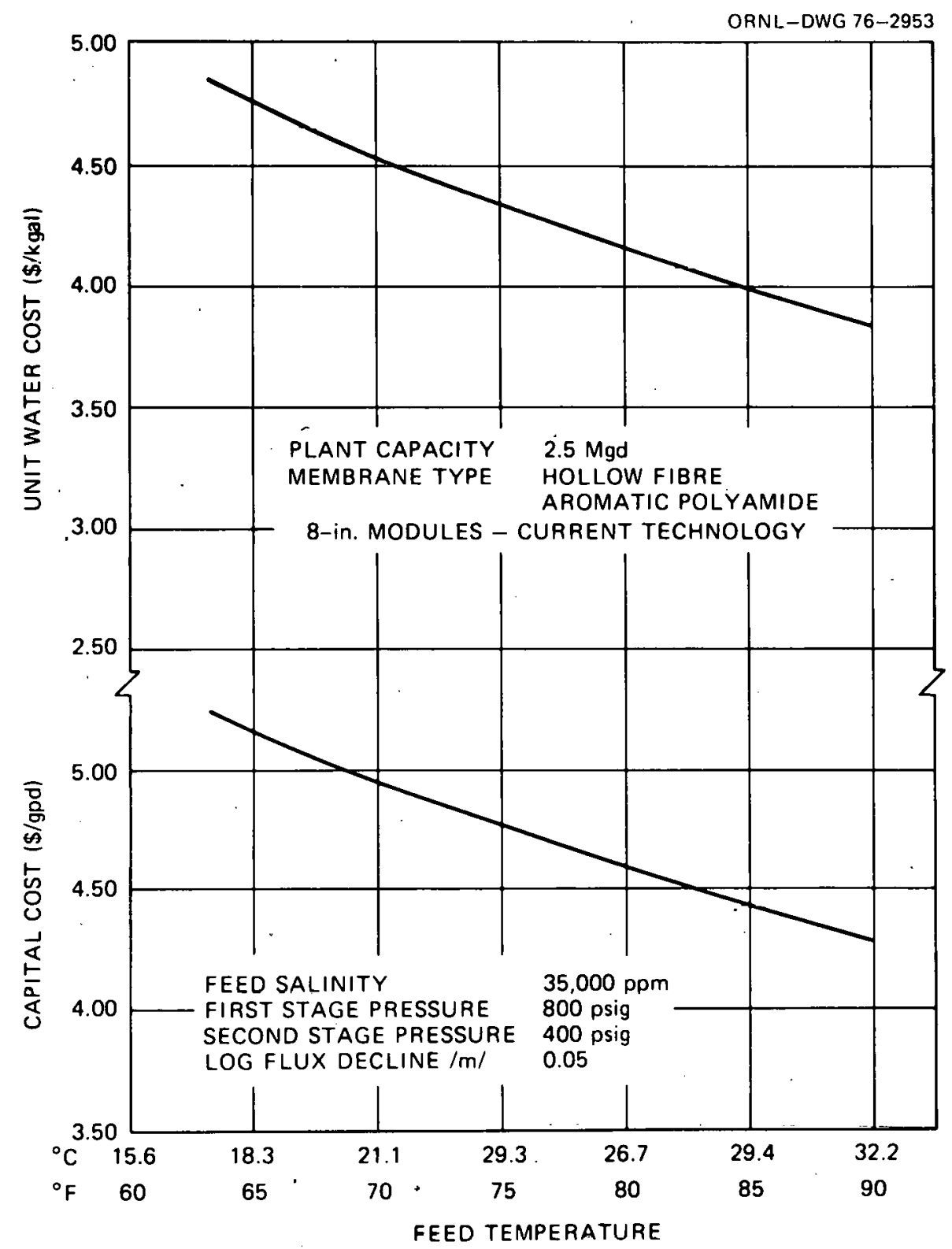

Fig. 6. Effect of feed temperature on capital and unit water costs. 
compared to an effect of approximately $3 \%$ imposed by feed temperature on membrane flux, or module productivity. It should, however, be emphasized that temperature has also an adverse effect on membrane life, predicted to be considerably lower at high temperatures. The overall effect of feed temperature on the economics of the RO process is therefore still pending on more reliable data concerning the effect on membrane life.

\subsection{Effect of System Pressure and Membrane Life}

The effect of system pressure and membrane life on unit water costs are illustrated in Fig. 7. Obviously, for a given membrane life and a constant unit membrane cost, a higher system pressure which strongly affects membrane flux would result in a considerably lower unit water cost. Membrane module cost, however, would be higher and membrane life lower at higher system pressure. The optimum pressure therefore cannot be determined without applying reliable data of membrane cost and membrane life versus pressure.

\subsection{Effect of Energy Cost and Comparison with Multistage Flash Distillation Plants}

From the untt water cost breakdown shown in lable 8 , it is evident that for an electrical power cost of $\$ 0.020 / \mathrm{kWhr}$, the energy cost in $\mathrm{R} n$ systems operating at pressure of 800 psig amounts to approximately 10-15\% of the total unit water cost. This percentage is relatively low in comparison to other desalting processes and is even lower than in nuclear dual-purpose plants using current technology, high temperature distillation processes. 2

An economic comparison was made between RO plants and small singleand dua1-purpose MSF plants recently evaluated at ORNL 2 using identical economic ground rules. The comparison with single-purpose plants versus energy costs is shown in Fig. 8 and that with dual-purpose plants in Fig. 9. The combined figures of process heat cost applied in MSF, and electrical power cost applied in both processes were based on the corresponding evaluations made for single- and dual-purpose distillation plants. ${ }^{2}$ 


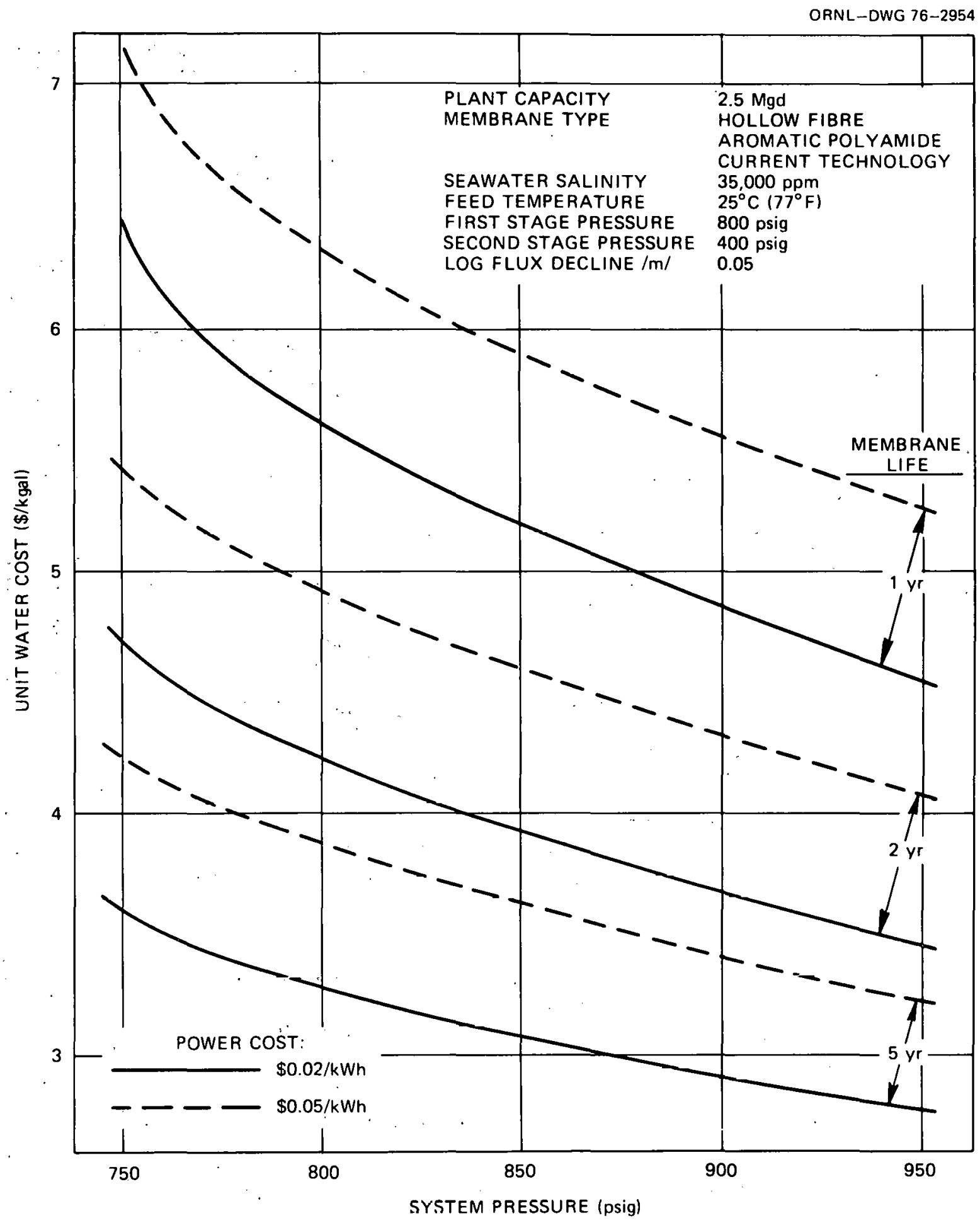

Fig. 7. Unit water cost vs system pressure and membrane life. 


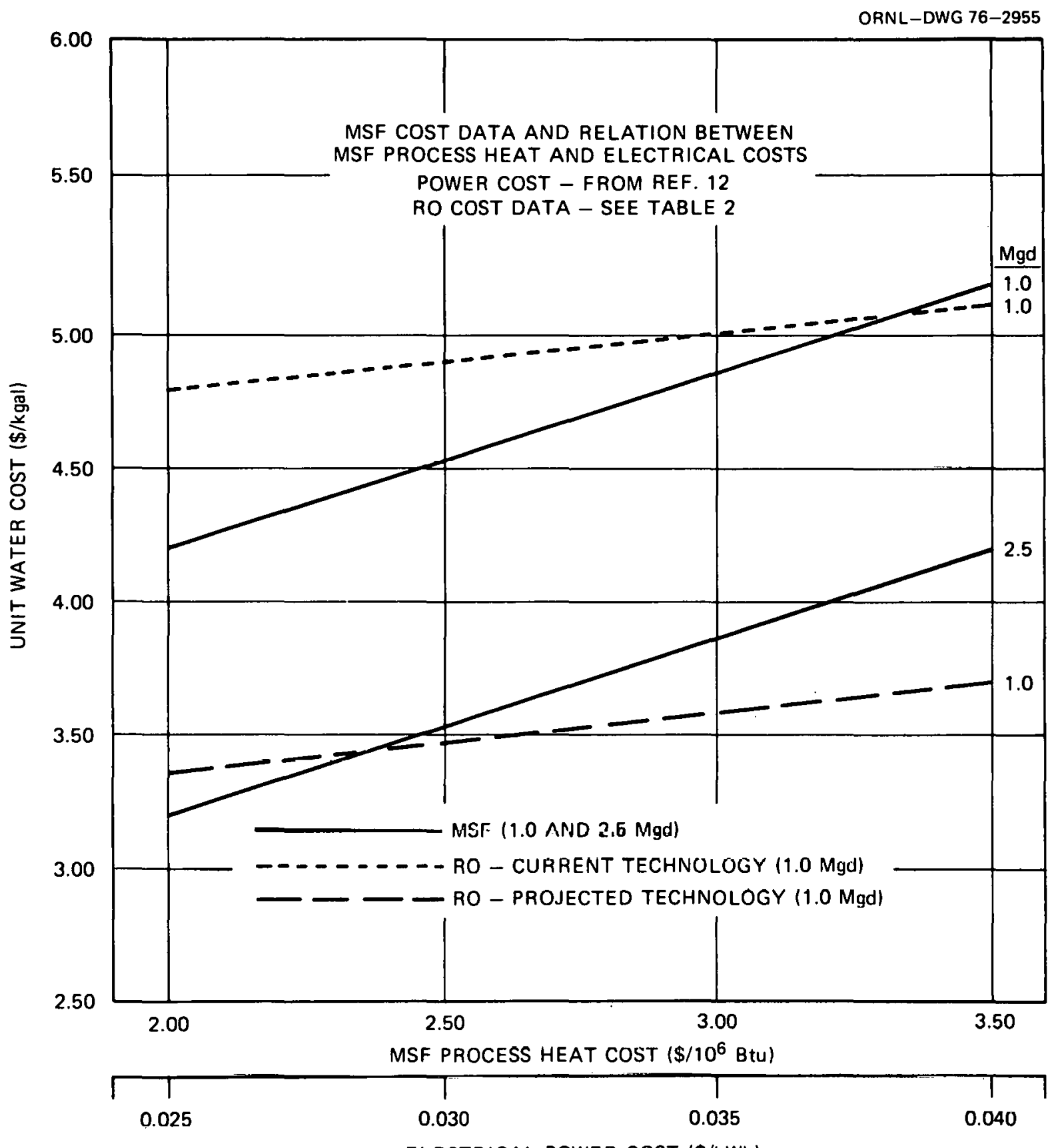

Fig. 8. Unit water costs from reverse osmosis and single-purpose multistage-flash plants vs energy costs. 


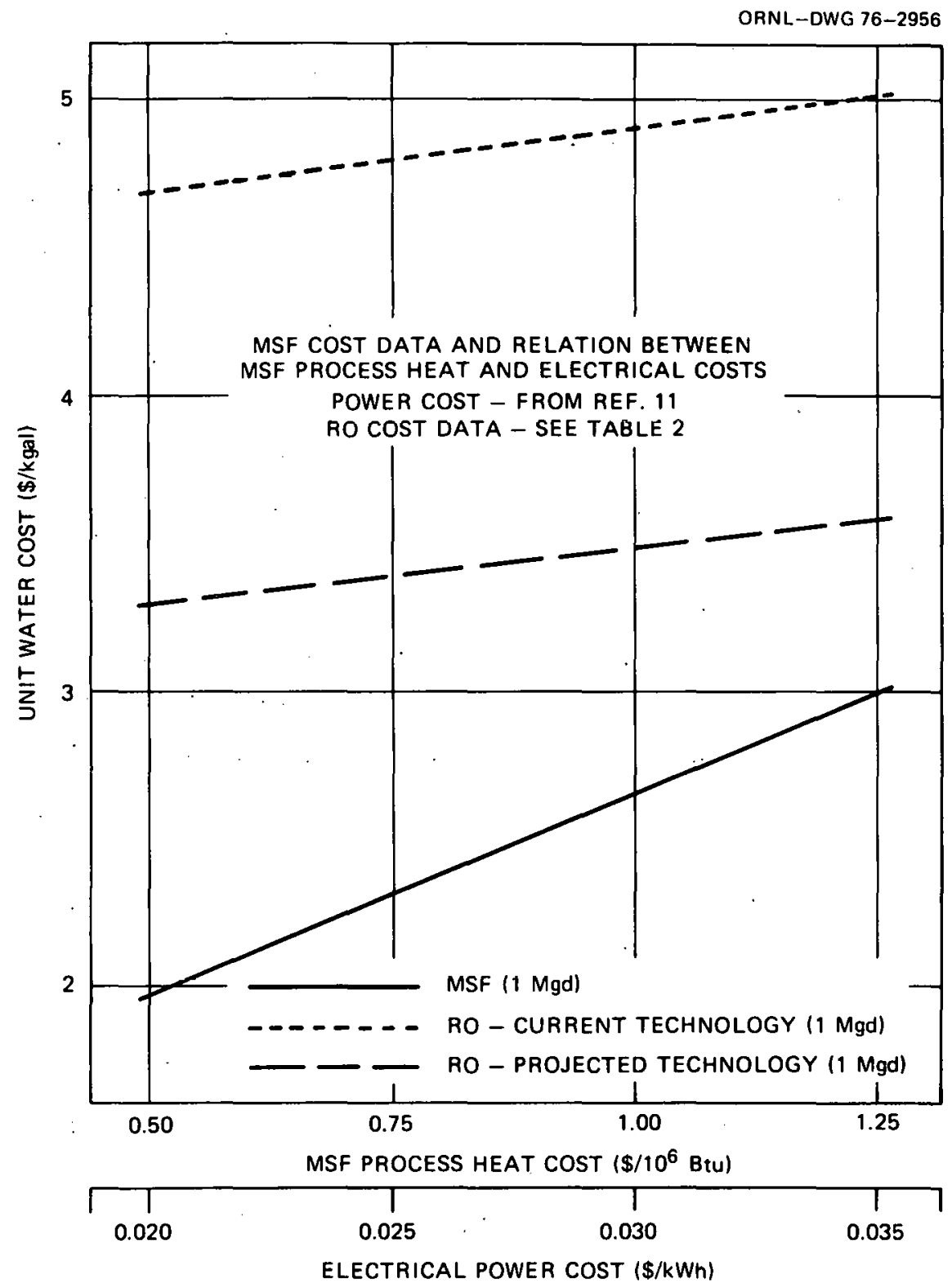

Fig. 9. Unit water costs from reverse osmosis and dual-purpose multistage-flash plants vs energy costs. 
From the results shown in Fig. 8, it is evident that current technology RO plants, based on the technological and cost assumption applied in the present study, might eventually be competitive in the 1-Mgd range with MSF single-purpose plants only at prevailing high energy cost. If, however, the projected Ro technology could be realized, Ro could also be competative at lower energy price levels even in the 2.5-Mgd range. It must be emphasized however, that this comparison is made for plants operating with seawater having a salinity of 35,000 ppm. For higher salinities at which the distillation processes are much less affected, the competitiveness of the RO process would be reduced considerably.

Based on the results shown in Fig. 9, it is evident that Ro seawater desalting plants cannot compete with dual-purpose MSF plants, even with the assumed projected technology and at high energy cost. In this case, the difference between the unit water costs obtained from both processes in the 1-Mgd range is quite small, especially when considering the accuracy of the results for both processes and the operational and cost uncertainties related to the Ro process for seawater desalination.

\subsection{Overall Sensitivity Analysis of Technological and Cost Parameters}

The present evaluation was based on a set of technological and cost parameters which.still have, at least in part, to be verified. As already discussed, the major unknown factors are membrane life, longterm performance, and the requirements for raw seawater pretreatment. However, several additional technological parameters, such as the largest applicable train size, the efficiencies of high pressure pumps and of the power recovery turbines and the cost of the seawater intake system, may also effect the economics of the Ro process considerably. Therefore, a brief sensitivity analysis of these and several other facluis was made in order to determine their effect on the unit water cost. As reference case for this investigation, a $12.5 \mathrm{Mgd}$ plant based on current technology was selected. 'lhe effect of these parameters, each varied singularly while all others were kept at their reference design values, is summarized in Table 9. The combined effect of varying several parameters 
Table 9. Effect of technological and cost parameters on the unit water cost from a 12.5-Mgd RO seawater desalting plant based on current technology

(Unit water cost from reference design $=\$ 3.89 / \mathrm{kgal}$ )

\begin{tabular}{|c|c|c|c|c|c|}
\hline \multirow{2}{*}{. } & \multirow{2}{*}{ Parameters varied } & \multicolumn{2}{|c|}{ Cost increase } & \multicolumn{2}{|c|}{ Cost savings } \\
\hline & & $\$ / \mathrm{kgal}$ & $\%$ & $\$ / \mathrm{kgal}$ & $\%$ \\
\hline \multirow[t]{2}{*}{1.} & Module and train size & & & & \\
\hline & $\begin{array}{l}\text { a. Smaller: module-4 in.; train-0.25 Mgd } \\
\text { b. Larger: module-12 in.; train-1.25 Mgd }\end{array}$ & +0.34 & +8.7 & -0.08 & -2.1 \\
\hline \multicolumn{6}{|c|}{ Un1t membrane cost (first stage) $-\$ / g p d$} \\
\hline$\cdot$ & $\begin{array}{l}\text { a. Higher: initial-1.0; replacement to } 0.80 \\
\text { b. Lower: initial-0.50; replacement to } 0.40\end{array}$ & +0.71 & +18.3 & -0.73 & -18.8 \\
\hline \multirow[t]{2}{*}{3.} & Membrane 11fe (first stage) - years & & & & \\
\hline & $\begin{array}{l}\text { a. Lower - i } \\
\text { b. Higher - } 3 \\
\text { c. Higher - } 5\end{array}$ & +1.45 & +37.3 & $\begin{array}{l}-0.51 \\
-0.91\end{array}$ & $\begin{array}{l}-13.1 \\
-23.4\end{array}$ \\
\hline \multirow[t]{2}{*}{4.} & Log flux decline $/ \mathrm{m} /$. (first stage) & & & & \\
\hline & $\begin{array}{l}\text { a. Higher }-0.08 \\
\text { b. Lower }-0.03 \\
\text { c. Lower }-0.02\end{array}$ & +0.41 & +10.5 & $\begin{array}{l}-0.24 \\
-0.35\end{array}$ & $\begin{array}{r}-6.2 \\
-10.0\end{array}$ \\
\hline \multirow[t]{2}{*}{5 . } & First stage pressure - psig & & & & \\
\hline & $\begin{array}{ll}\text { a. } & \text { Lower }-750 \\
\text { b. Higher }-900 \\
\text { c. Higher }-1000\end{array}$ & +0.44 & +11.3 & $\begin{array}{l}-0.64 \\
-0.92\end{array}$ & $\begin{array}{l}-16.5 \\
-23.7\end{array}$ \\
\hline \multirow[t]{2}{*}{6 . } & Feed temperature $-{ }^{\circ} \mathrm{C}$ & & & & \\
\hline & $\begin{array}{l}\text { a. Lower }-18\left(65^{\circ} \mathrm{F}\right) \\
\text { b. H1gher }-30\left(86^{\circ} \mathrm{F}\right)\end{array}$ & +0.48 & +12.3 & -0.31 & -8.0 \\
\hline \multirow[t]{2}{*}{7.} & Overall efficiency of high préssure pumps, $\%$ & & & & \\
\hline & $\begin{array}{l}\text { a. Lower }-68 \\
\text { b. Higher }-84\end{array}$ & +0.07 & +1.8 & -0.07 & -1.8 \\
\hline \multirow[t]{2}{*}{8.} & Overall efficiency of power recovery turbine, $\%$ & & & & \\
\hline & $\begin{array}{l}\text { a. Lower }-60 \\
\text { b. Higher }-75\end{array}$ & +0.01 & +0.3 & -0.03 & -0.8 \\
\hline \multirow[t]{2}{*}{9 . } & Cap1tal cost of pretreatment system, $\%$ & & & & \\
\hline & $\begin{array}{l}\text { a. Higher }-+50 \\
\text { b. Lower }-50\end{array}$ & +0.10 & +2.57 & -0.10 & -2.57 \\
\hline \multirow[t]{3}{*}{10 . } & Capital cost of seawater intake, $\%$ & & & & \\
\hline & $\begin{array}{l}\text { a, Higher }-+50 \\
\text { b. Lower }-50\end{array}$ & +0.05 & +1.29 & -0.05 & -1.29 \\
\hline & Combined effect of $3 a, 9 a$ and $9 b$ & +1.62 & +41.6 & & \\
\hline 11 . & Combined effect of all cost increasing factors & +6.40 & +164.5 & & \\
\hline 12. & Combined effect of $1 b-4 b$ and $7 b$ to $10 b$ & & $\cdot$ & -1.12 & -28.8 \\
\hline 13. & Combined effect of lb lu lob & & & -2.08 & -53.5 \\
\hline 14. & Combined effect of largest potential cost savings & & & -2.41 & -62.0 \\
\hline
\end{tabular}


simultaneously, representing overall sets of optimistic and pessimistic assumptions were also evaluated and are shown in Table 9.

The results of the sensitivity analysis emphasized again the very strong effect of membrane life on the unit water cost. However, the other factors characterizing the membrane, such as $\log$ flux decline and, of course, the unit membrane cost, will also have a major influence on the potential competitiveness of the Ro process for seawater desalting. The cost of the pretreatment and the seawater systems, as well as the other "nonmembrane" factors, such as the efficiencies of the pumps and the power recovery turbine, have each alone only a minor effect.

The combination of several of these factors may however increase or decrease the unit water cost substantially. 


\section{REFERENCES}

1. S. A. Reed, "The Impact on Increased Fuel Costs and Inflation on the Cost of Desalting Seawater and Brackish Waters,"ORNL-TM-5070 Revised, January 1976.

2. P. Glueckstern, J. V. Wilson and S. A. Reed, "RO-75: A Fortran Code for Calculation and System Design Optimization of Reverse Osmosis Seawater Desalination Plants," ORNL-TM-5231, December 1976.

3. Ralph Stone and Co., Inc., "The Chula Vista, California, Pilot Plant Testing Program to Evaluate Seawater. Pretreatment Methods for Reverse Osmosis," OSW Research and Development Progress Report No. 890, September 1973.

4. N. W. Rosenblatt, "Seawater Desalination by Reverse Osmosis," presented at the Special Symposium "Marine Chemistry in the Coastal Environment," 169th ACS National Meeting, April 8-10, 1975, Philadelphia, Pa.

5. D. G: Thomas, "Engineering Development of Hyperfiltration with Dynamic Membranes, IV, Economic Analysis Desalination," 15 (1974), pp. 343-369.

6. W. G. S. Fort, "Computer Codes for Office of Saline Water Program Analysis, Part V: MSF-21: A Fortran Code for the Rapid Calculation or Optimization of Multistage Flash (MSF) Desalination Plants," ORNL-TM-3535, February 1972.

7. W. G. S. Fort, J. V. Wilson, Ibid., Part VI: VTE-21: A Fortran Code for the Rapid Calculation or Optimization of Vertical Tube Evaporator (VTE) Desalination Plants," ORNL-TM-3535 (Part VI).

8. P. Glueckstern, J. V. Wilson and S. A. Reed, "Design and Cost Modifications of ORNL's Computer Programs MSF-21 and VTE-21 for Evaluation of Multistage Flash and Vertical Tube Evaporators," ORNL-TM-5230, December 1975.

9. K. E. Hickman et al., "Pumping and Energy Recovery Systems for Reverse 0smusis Desalination Ylants," OSW Research and Development Report No. 457, August 1969.

10. Fluor Corporation, "Engineering and Economic Study of Reverse Osmosis Brackish Water Desalting Plants," Final Report to Office of Saline Water, October 1972, published in Membrane Digest, 1(4), Spring 1973.

11. P. Glueckstern and S. A. Reed, "A Comparative Investigation of the Economics of Seawater Desalting Based on Current and Advanced Dist1llat1on Concepts," ORNL-TM-5232, December 1975. 


\section{THIS PAGE \\ WAS INTENTIONALLY \\ LEFT BLANK}


Appendix A

COMPUTER PRINTOUT OF A 2.5-Mgd RO PLANT BASED ON CURRENT TECHNOLOGY 


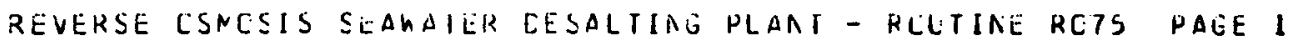

$\begin{array}{lr}\text { PLANT CAPACITY - MCD } & 2.5 C 0 \\ \text { UNIT CCST CF CESALIEC WATER - CENTS PER KILCOALLLN } & 460.518 \\ \text { CAPITAL COST CF PLANIICIRECT+INCIRECTI- MILLICNS CF CULLARS } & 9.431 \\ \text { POWER RECEVERY - YES } & \end{array}$

THE PLANT HAS BEEN CFTINIZED

CLST SLNARY HAGE

\begin{abstract}
CAPITAL CCNPCNENTS
CAPITAL CCMPCNENTS

MUDULES ANE HCLSING PUPPS ANE NCTCRS

VALVES AND PIPIAG

INSTRUMENTS

ELECTRICAL.

PRETREATNEAT SYSTEN

POSTTREATMENT SYSTEN SEA-WATER IATAKE

SITE, BLCGS, CRAAES

PONER RECCV. TLRBIAE
\end{abstract}

TOTAL CAPITAL

TGIAL INVESTNENT, $\$ C I R+I N O$

SPECIFIC INVESTNENT, $\$ / \mathrm{CPC}$

MENGRANE REPLACENENT

OPERATING CONPONENTS

---D---D --- - - - - -

PCWER

CHEMICALS

OPERATING

MAINT + SUFPLIES

TOTAL CPERATING

TOTAL (CAP+RE TUB +EP)

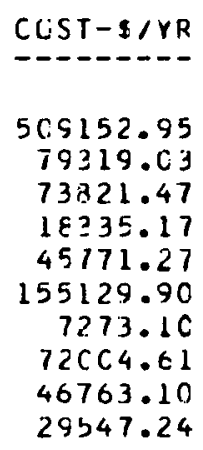

$1 C 37117.83$

133.7138
CCST-SOIRECT

3490350.00

488441.53

454587.88

112906.79

281856.54

455280.01

44787.27

443399.77

287964.17

181949.99

6741523.96

9431229.91

3.77249
1194132.14

811194.66
284758.03
$178 t 68.69$
$6 t 018.6 C$

1340639.98

3571889.95
104.5859

36.7134

23.0355

8.5117

172.8464

$46 C .5177$ 
CCST FACTCRS

COST CH FLIRER, C/KWHR

ANNLAL CHARGE RATE

INTERESI KAIE

HIOHER CCST FACTCR

PLANT LOAD FACTOR

PLANT LIFE, YEARS.

$$
\begin{aligned}
& \text { j. CCecec } \\
& \text { i. } 11 \in i 79 \\
& \text { j. } 1 \text { Cccoc } \\
& \text { 1. } 19 \text { त576 } \\
& \text { C. } 85 \mathrm{CCCO}
\end{aligned}
$$

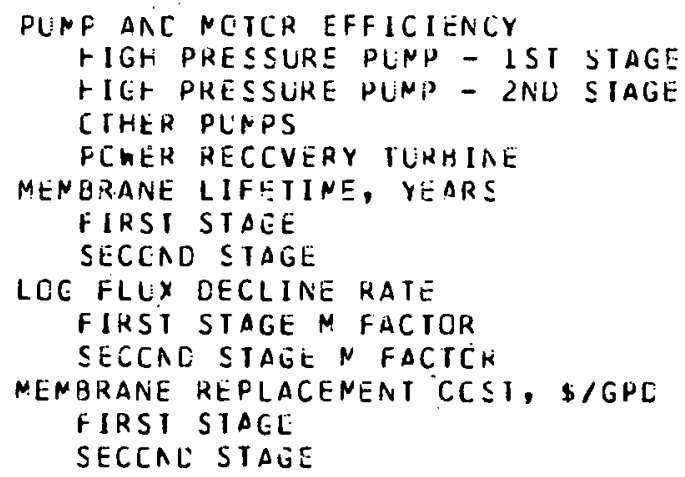

$$
\begin{array}{r}
0.760 \\
0.760 \\
0.820 \\
0.650 \\
2.00 \\
3.00 \\
-0.0500 \\
-0.0500 \\
C .55 \\
C .15
\end{array}
$$

I SUNNARY CF PLANT DATA

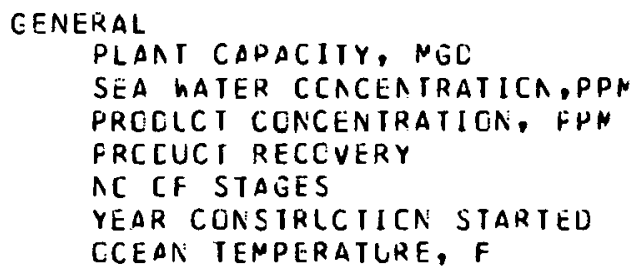

II CESCRIFIICA CF PFYSICAL PLANI

ICTAL PLANT AREA, SG FT

NO CF TRAINS

NC EF MLCULES

II I NEMBRANE PARANETERS MEMBRANE TYPE MOCLLE CUISICE CIAM.. IN. SHELL CIMEASICAS CLISIDE CIAM., IN. LENGTH, IN.

NC. CFF MOCLLFS IN SHELL NEMBRANE SLRFACE, S6.FT. NEMINAL OPERATING PRESSLRE, PSI ACNINAL PRCCUCT RECLVEKY ACAIAAL REJECTICN RATE INITIAL PRCDLCTIVITY, GPDINOCLLE REFERENCE FEEC CCNCENTRATICN, PPM REFERENCE FEEC TEMPERATLRE, \& MENERANE LIFE, YEARS,

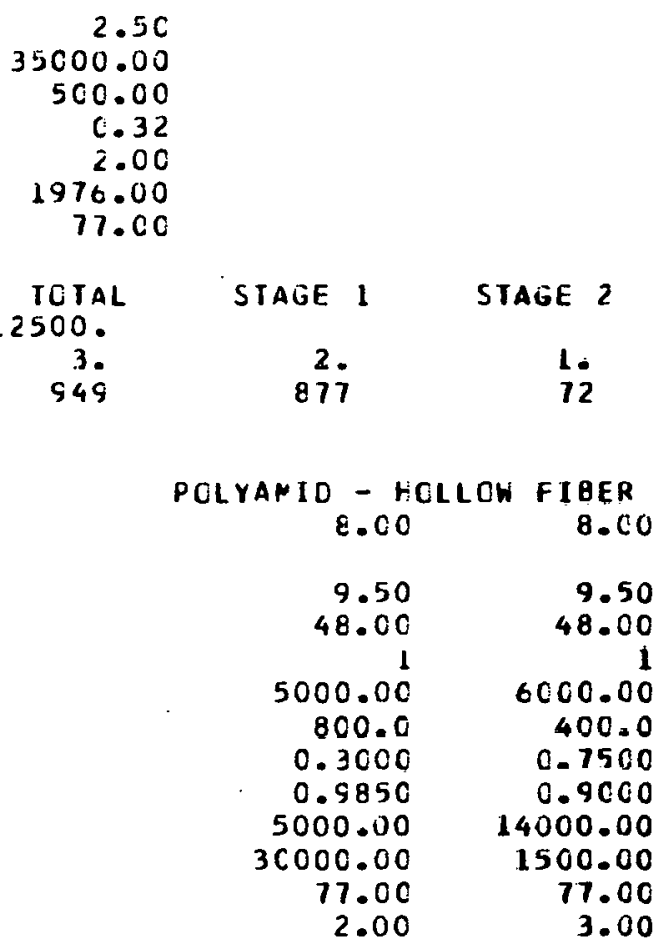


IV ACTUAL CFERATINL PARANETERS

NCLLLE IALEI PRESSURE, PSI

$80 \mathrm{C} .0 \mathrm{C}$

$4 \mathrm{CO} .0 \mathrm{C}$

PRCCLCI RECCVERY

SALT PASSAEE

FIRSI STAGE FEEL CCNCENIRAIICN,PPM

0.3225

0.0192

0.8993

MCCLLE PRCCLCTIVITY, GPC

INITIAL

EAC CF LIFETIME

34679 .

0.2020

WEIUFTEL AVERAGE

IUTAL STAGE PRCDLCTILN, MGL

STAEL PROLLCT QLALITY, PPN

NCLLLE REJECTICA RATE

BLENOINE RAIIO, 2NC SIAGE/TOTAL

$3897.17 \quad 14379.37$

$2802.74 \quad 10133.73$

$2950.26 \quad 10667.08$

$2.5869 \quad 0.7764$

$664.75 \quad 134.30$

$0.980 \mathrm{e} \quad 0.7980$

0.3106

$\checkmark$ PUMPING PARAMETERS

1ST STAGE HIGH PRESSURE

2NE STAGE HIGH PRESSURE

SEA-WATER LELIVERY

PRCCLCT

TOTAL

PCWER RECOVERY TUKUINE

NLMBER CF PLANT CALLS 1CI

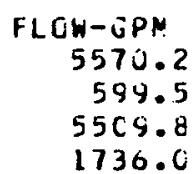

3773.8
HEAD-FT

1840.0

920.0

138.0

92.0

1716.9
POWER-KW

2551.1

123.5

175.4

36.8

2924.1

745.3 
Appendix B

COMPUTER PRINTOUT OF A 2.5-Mgd RO PLANT

BASED ON PROJECTED TECHNOLOGY 


\author{
PLANT CAPACIIY - MGC \\ UNIT COST GF CESALTEL WATER - CENIS PER KILGUALLON \\ CAPITAL CCST CF PLANTICIRECT+IACIRECT)- MILLICNS OF DOLLARS \\ POWER RECOVERY - YES \\ 2.500 \\ 326.385 \\ 7.261
}

THE PLANT HAS BEEN CFTINIZEC

\section{CLST SUMMARY PAGE}

\begin{tabular}{|c|c|c|}
\hline CAPITAL CCAPCNENTS & $\begin{array}{l}\text { COST-\$IYR } \\
-----D\end{array}$ & CCSI-C/KGA \\
\hline $\begin{array}{l}\text { MODULES ANC HCLSING } \\
\text { PUMPS AND MCIORS } \\
\text { VALVES AND FIPING } \\
\text { INSTRLMENIS } \\
\text { ELECTRICAL } \\
\text { PRETREATNENT SYSTEM } \\
\text { PCSTTREATMEAT SYSTEN } \\
\text { SEA-WATER INTAKE } \\
\text { SITE, BLCGS, CAANES } \\
\text { PCHER RECCV. TLREINE }\end{array}$ & $\begin{array}{r}342284.51 \\
74725.63 \\
47756.64 \\
10522.51 \\
4162 C .32 \\
143201.72 \\
7267.32 \\
65522.85 \\
46725.98 \\
27677.62\end{array}$ & $\begin{array}{r}44.1302 \\
9.6342 \\
6.1572 \\
1.3566 \\
5.3660 \\
18.4628 \\
0.9370 \\
8.4477 \\
6.0243 \\
3.5684\end{array}$ \\
\hline TOTAL CAPITAL & 807305.11 & 104.0845 \\
\hline $\begin{array}{l}\text { TOTAL INVESIMENT, } \\
\text { IEIR+INC } \\
\text { SPECIFIC INVESIMENT, } \\
\text { \$IGPC }\end{array}$ & & \\
\hline MENBRAAE REPLACENEAT & 477288.94 & 61.5361 \\
\hline OPERATING CCMPONENIS & & \\
\hline $\begin{array}{l}\text { PCWER } \\
\text { CHEMICALS } \\
\text { OPERATING } \\
\text { MAINT + + SUPPLIES }\end{array}$ & $\begin{array}{r}763246.87 \\
254192.32 \\
17866 E .69 \\
5 C 824.76\end{array}$ & $\begin{array}{r}98.4641 \\
32.7726 \\
23.0355 \\
6.5527\end{array}$ \\
\hline TOTAL CPERATING & 1246932.63 & 160.7649 \\
\hline TOIAL (CAP+RE I $(B+C P)$ & $253152 t .68$ & 326.3854 \\
\hline
\end{tabular}


CCST FACICRS

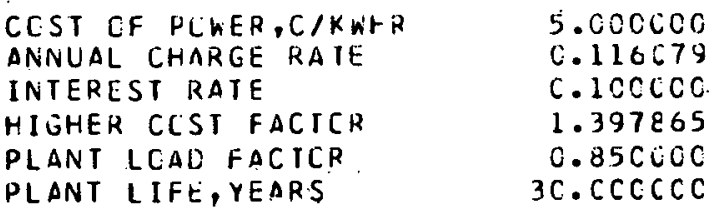

PUMF ANC NCICR EFFICIENCY HIGH: PRESSURE PUNP - IST STAGE FIGH PRESSURE PUNP - 2NC STAGE CTHER PUNPS PCWER RECCVERY TURBIAE

MENBRANE LIFETINE, YEARS FIRSI STAGE SECCAD STAËE

L.CG FLUX CECLINE RATE HIRSI SIAGE N FACTOR SECCAD STAUE N FACTOK NENBKANE REFLACENEAT CCST, \$/GPC FIRS I STAGL SECONC STAGE

I SUMAARY CF PLANT CATA

GENERAL

PLANT CAPACIITY, MGU

SEA WATER CCNCEATRATIUN,PPM

PRCCLCT CENCENTRATICN, FPN

PRC:CLCT RECCVERY

NC CF STAEES

YEAR CCASTRLCTICN STARTEC

UCEAN IENPERATURE, F

$$
\begin{array}{r}
2.50 \\
35000.00 \\
500.00 \\
6.35 \\
2.00 \\
1976.00 \\
77.00
\end{array}
$$

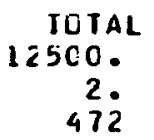

SIAGE 1

431
STAEE 2

41

II I NEMBRANE PARAMETERS

NEMGRANE TYPE

MOCLLE OUISILE CIAM., IN.

SHELL CINEASICNS

CUTSIDE CIAN., IN.

LENGTH, IN.

NC. CF NOCULES IN SHELL

MENERANE SLRFACE, SG.FT.

NEN INAL OPERATING PRESSLRE, PSI

NLNINAL PRCLLCT RECOVERY

NCNINAL REJECTICA RATE

INITIAL PRCCLCTIVITY, GFD/MCCULE

REFERENCE FEEC CONCENIRATICN, PPM

REFERENCE FEEC TEMPERATLRE, F

NENERANE LIFE, YEARS, 
IV ACTUAL OPERATING PARANETERS

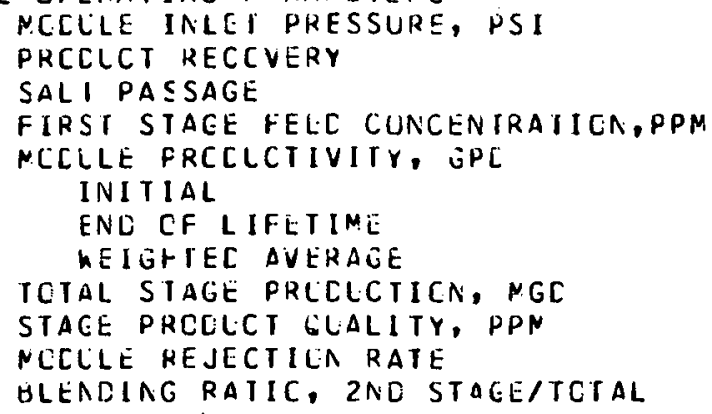

$80 \mathrm{C} .0 \mathrm{C}$

0.3625

0.0212

34556 .

$7237 . A C$ 5867.11 6048.57

2.6102

730.90

0.9788
FLOW-GPM $50 \mathrm{CO} .1$
765.2
4923.5
1736.0

ISI SIAEE FIUH PRESSURE
2NE SIAGE HIGH PRESSURE SEA-WATER OELIVERY PRCCUCT

3187.5

PCWER RECOVERY TURGINE

1722.1
$4 \mathrm{CC} . \mathrm{CO}$

0. $9 \mathrm{CCO}$

0.2037

28577.51

23165.52

23881.98

0.9918

148.88

0.7963

0.3967

PUWER-KW

2290.0

157.7

156.7

36.8

TEIAL

NUNBER CF PLANT CALLS ICI

C

2678.6 628.5 
Appendix C

CONVERSION FACTORS

Multiply

Million of gallons per day (Mgd)

Dollars per gallon per day 264.2 (\$/gpd)

Pounds per square inch (psi) 703.1

Inches (in.)

Square feet $\left(f t^{2}\right)$

Gallons per minute per square foot $\left(\mathrm{gpm} / \mathrm{ft}^{2}\right)$
By

$3.785 \times 10^{3}$

2.54

0.0929

0.7451
To obtain

Cubic meters per day $\left(\mathrm{m}^{3} / \mathrm{d}\right)$

Dollars per cubic meter per day $\left(\$ / \mathrm{m}^{3} \cdot \mathrm{d}\right)$

Killograms per square meter $\left(\mathrm{kg} / \mathrm{m}^{2}\right)$

Centimeters $(\mathrm{cm})$

Square meters $\left(\mathrm{m}^{2}\right)$

Liters per second per square meter (1iter/sec. $\mathrm{m}^{2}$ ) 
THIS PAGE

WAS INTENTIONALLY

LEFT BLANK 
ORNL/TM-5231

\section{Internal Distribution}

1. T. D. Anderson

2. S. J. Ball

3. D. F. Cope

4. W. B. Cottre11

5. F. L. Culler

6. G. C. Fee

7. M. J. Goglia

8. R. F. Hibbs

9. R. E. MacPherson

10. W. J. McCarthy, Jr.

11. J. W. Michel

12. J. S. Johnson

13. J. E. Jones Jr.

14. H. Postma
15-39. S. A. Reed

40. M. W. Rosenthal

41. M. R. Sheldon

42. M. J. Skinner

43. I. Spiewak

44. J. J. Taylor

45. D. B. Trauger

46. W. J. Wilcox

47-51. J. V. Wilson

52-53. Central Research Library

54. Document Reference Section

55-57. Laboratory Records Department

58. Laboratory Records, RC

\section{External Distribution}

59-63. Pinhas Glueckstern, Desalting Dept., Mekoroth Water Co., 9 Lincoln Street, Tel Aviv, Israel.

64-68. W. F. Savage, Advanced Concepts Evaluation Branch, U.S. Energy Research and Development Administration, Washington, D.C. 20545

69-70. Director, Division of Nuclear Research and Applications, ERDA, Washington, D.C. 20545

71. Director, Reactor Division, ERDA, ORO

72. Research and Technical Support Division, ERDA, ORO

73. G. H. Corey, 6600 West 13th Avenue, Denver, Colorado 80214

74-100. Technical Information Center, ERDA 